\title{
Chemical Composition and Antimicrobial Activity of the Essential oils of 14 known Ficus species - A Concise Review
}

\author{
Ayodele Dorcas Adeyemi 1,2,*(i), Chizurum Chibueze Oluigbo ${ }^{3, *(\mathbb{D})}$, Akintomiwa Olumide Esan 2,4,*(D), \\ Muibat Olabisi Bello $^{2}$ (D), Sunday Olusegun Oladoye ${ }^{2}$ (D) , Chibuzor Precious Emmanuel ${ }^{5}$ (D), Ekpedeme \\ Effiong 1 iD
}

1 Department of Chemistry, Hallmark University Ijebu-Itele Ogun State, Nigeria; royalfemi@gmail.com (A.D.A.); emmydiamond99@gmail.com (E.E.);

2 Department of Pure and Applied Chemistry, Ladoke Akintola University of Technology, P.M.B 4000, Ogbomoso Oyo State, Nigeria; royalfemi@gmail.com (A.D.A.); aoesan@lautech.edu.ng (A.O.E); mobello@lautech.edu.ng (M.O.B.); sooladoye@lautech.edu.ng (S.O.O.);

3 Department of Biochemistry, Hallmark University Ijebu-Itele Ogun State, Nigeria; chizurumoluigbo@gmail.com (C.C.O.);

4 School of Chemical Sciences, Universiti Sains Malaysia, 11800, Penang, Malaysia; aoesan@lautech.edu.ng (A.O.E.);

5 Department of Microbiology, Micheal Okpara University of Agriculture, Umudike, Abia State, Nigeria; emmanuel.chibuzor@mouau.edu.ng (C.P.E.);

* Correspondence: royalfemi@gmail.com (A.D.A.);

Scopus Author ID 57215188747

Received: 5.10.2021; Revised: 10.11.2021; Accepted: 15.11.2021; Published: 5.12.2021

Abstract: Compounds useful for drugs, cosmetics, and food have been obtained directly or indirectly from living organisms over the years. However, there has been a renewed interest in getting useful compounds from living organisms, especially plants. Essential oils, interchangeably called volatile oils, are bioactive compounds found in minute quantities in some plants. Essential or volatile oils have been known for years to find usefulness in foods, drugs (antimicrobial, antifungal), and cosmetics. This review attempts to summarize information on the essential oil from Ficus species concerning their morphology, pharmacology, bioactivity, and application. This was achieved by gathering information on essential oils from different Ficus species. Essential oils from Ficus species are a good source of bioactive compounds for use in drug, food, and cosmetic industries. It is worthy to note that Nigerian Figs were characterized by the high presence of phytol and 6,10,14-trimethyl-2-pentadecanone, and these compounds are, therefore, seen as markers. Furthermore, this review presents numerous insights on how to best harness the different potentials of the essential oils and possibilities to be examined.

Keywords: essential oil; Ficus plants; bioactive compounds; phytol; drugs; cosmetics.

(C) 2021 by the authors. This article is an open-access article distributed under the terms and conditions of the Creative Commons Attribution (CC BY) license (https://creativecommons.org/licenses/by/4.0/).

\section{Introduction}

Of recent, there has been a shift in the use of conventional therapies to treat ailments to other natural methods, as interest has grown over the last decade in seeking alternative therapies from the phytochemicals present in plants of natural origin [1-3]. It is no longer news that these essential oils and the different extracts contained in plants could be used in conventional drugs to treat myriads of infectious diseases [3]. A group of plants called aromatic plants is implicated in traditional medicine due to the high level of essential oils [4]. In the last few years, the use of these aromatic plants, as well as their essential oils, have increased, as there has been a great 
deal of input both industrially and research-wise [5] to see to their usefulness in food [6,7], drugs [8] and as beauty products [7,9,10] of which Ficus species have been an essential part. Presently, about 3000 of these oils are known, with $10 \%$ of them garnering quite a high level of importance economically [11].

Essential oils can be extracted from the leaves [4,12], stem barks [13], fruits [14,15], seeds [7,16], latex [17] and roots [18] of plants. Ficus (Moraceae) is one of the largest genera of angiosperms, including trees, hemiepiphytes, shrubs, creepers, and climbers located in the tropics and subtropics worldwide, totaling over 800 species [19]. The genus Ficus also contains vines, shrubs, and woody trees located in forests, tropical and subtropical areas around the globe [20]. This genus is widespread across warmer parts of Asia, Africa, America, and Australia [21]. Collectively known as fig trees, the most popular Ficus species is the common Fig (Ficus carica Linn), the source of the commercial fruit-fig [22]. This large genus with high nutritional and economic value plays a vital role as a genetic resource, making up a good and significant part of the biodiversity in the rainforest's ecosystem [23]. Animals in the tropical habitat, which are consumers of fruit, see figs as a good source of nourishment [24].

Some examples of the different species of Ficus plant include; Ficus aspera G.Forst (clown fig), Ficus lacor Buch.-Ham (Pakur tree), Ficus auriculata Lour. (Roxburgh fig), Ficus asperifolia Miq, Ficus benghalensis L (Indian banyan), Ficus altissima Blume (Council tree), Ficus benjamina L (weeping fig), Ficus carica L (common edible fig), Ficus binnendykii (Miq.)Miq. (narrow-leaf ficus), Ficus celebensis Corner (willow ficus), Ficus glomerata, Ficus capensis Thunb, Ficus elastic (Indian rubber tree), Ficus exasperata Vahl, Ficus deltoidei Jack (mistletoe fig), Ficus lingua Warb. ex De Wild. \& Dur. (box-leaved fig), Ficus lyrata (fiddleleaf fig), Ficus macrophylla Desf. ex Pers. (Moreton Bay fig), Ficus saussureana DC., Ficus microcarpa L (Chinese banyan), Ficus nitida, Ficus palmate Forssk, Ficus pseudopalma Blanco (Philippine fig), Ficus pumila L (creeping fig), Ficus polita Vahl, Ficus racemosa L, Ficus religiosa L (bo tree or sacred fig), Ficus retusa L, Ficus rubiginosa Desf, Ficus sagittata J.Konig ex Vahl, Ficus stricta (Miq.) Miq, Ficus subulata Blume, Ficus sycomorus L, Ficus tikoua Bureau (Waipahu fig) and Ficus tsiela Roxb [25].

In this review, some Ficus plants' essential oils' morphological, pharmacological, and phytochemical attributes are enumerated. This study focused on the essential oils of Ficus plants with a special emphasis on their phytochemical components, usefulness, bioactivity, and insight into some of the important species.

\section{Essential Oils}

Essential oils are complex mixtures of natural origin that may comprise about 20-60 constituents of varying concentrations [26]. Essential oils are also referred to as volatile or ethereal oils, are odorous (possess fine fragrance) compounds found only in a small percentage of kingdom Plantae (about 10\%) [27,28]. Their synthesis is completed in the petals and has been observed in numerous flowers. They are stored in special brittle secretory structures, such as secretory ducts, glands, secretory hairs or resin ducts, and secretory cavities in plants [28-37]. Essential oil is hydrophobic; thus, it is not quite soluble in water and other polar solvents. However, this mostly yellow-color solution is highly soluble in nonpolar solvents [38]. Three biosynthetic pathways play an important role in producing these oils in plants; the mevalonate pathway, the methyl-erithrytol-pathway, and the shikimic acid pathway yielding sesquiterpenes, mono- and diterpenes, and phenylpropenes, respectively [39]. Various plants 
with high essential oil yield content implicated commercially are termed "Essential oil plants" [40]. The Jasmine (Jasminum sambac (L.) Aiton), rose (Rosa sp.), and tuberose (Polyanthes tuberosa L) are examples of essential oil plants, as they produce large quantities of volatile compounds [39].

Plants use essential oils as means of defense, internal messengers, as well as pollinating agents, attracting insects for pollination [16,40,41]. Various methods suitable for extracting these essential oils exist, but majorly, steam/water distillation, hydro-distillation, and steam distillation are used for this process [37,42-45]. Among the distillation methods for extraction, hydrodistillation is the most common, oldest, and easiest method often employed. Some researchers are interested in the volatile constituents, compounds or aroma active compounds in essential oils; therefore, they explore other methods, which include: solid-phase microextraction (SPME) [46-49], solvent-assisted flavour evaporation (SAFE) [50], supercritical fluid extraction (S.F.E.) [51,52], simultaneous distillation extraction (SDE) [27,53], solvent-free microwave extraction (SFME) [54], and the purge-and-trap technique [53,55-57]. Some researchers reported that if one is interested in genuine essential oils and active aroma compounds, hydrodistillation may not be the best choice because of the high temperature [47] involved. It is crucial to mention that SPME as a method is focused on aroma profile analysis based on the qualitative composition of essential oil. It is gaining cognizance because of advantages such as energy-saving, reduction in extraction time, and preservation of thermo-labile components of essential oils from degradation considering the high temperature required for extraction when using the conventional hydrodistillation or steam distillation method [46,52]. Other advantages of SPME are the use of a relatively small amount of sample for extraction [48], the high degree of automation [47], and the non-extraction of non-volatile substances [47,48]. Sometimes a modified SPME known as HS-SPME (Headspace solid-phase microextraction) is often used, for example, the extraction of volatile compounds from the fruit of Seseli libanotis (L.) W.D.J.Koch was compared using hydrodistillation and HS-SPME [48]. Some other Researchers [47] also compared the extraction of essential oil and related compounds from aromatic plants using five different methods of which SPME was among the methods compared. The researchers reported that SPME is the most useful method for the extraction of essential oil; the remaining four methods are hydrodistillation, supercritical fluid extraction, solvent extraction, and accelerated solvent extraction. The researchers, however, documented that hydrodistillation will be viewed as the best method when it comes to essential oil extract and essential oil content because essential oil is defined in pharmacopeias according to the use of this procedure, but to investigate genuine odorous compounds, hydrodistillation often leads to the transformation of sensitive genuine odorous compounds. The essential oil from cultivated and wild lotus (Nelumbo Lucifera Gaertn) was compared using three different extraction techniques. The researchers documented that SPME is most favorable for the highly volatile components of essential oils [58].

Solvent-assisted flavor evaporation (SAFE) is an efficient method of extracting volatiles and has been reported to extract with high efficiency with emphasis on avoidance of pyrolysis of components of essential oil leading to oils with fresh flavor [50]; SAFE and hydrodistillation was compared in the extraction of volatile compounds from Magnolia obovata Thunb leaves [50].

The use of a volatile and non-toxic solvent such as carbon dioxide for extraction has made S.F.E. gain attention as a method of extraction coupled with the protection of extracts by 
$\mathrm{CO}_{2}$ from both solvent contamination and thermal degradation [47,51], though it has been reported to sometimes extract non-essential oil and non-volatile compounds [47].

SDE is a method of extraction that combines distillation with solvent extraction. , The combination of the two techniques (distillation and solvent extraction) has led to the avoidance of the setback linked to the two techniques. Simultaneous distillation extraction was compared with hydrodistillation in the extraction of essential oil from Aloe debrana Christian roots, and it was reported that SDE was a more efficient method in extracting more compounds from the roots of Aloe debrana when compared to hydrodistillation [27]. SDE was reported to be more advantageous in terms of the time consumed, extraction efficiency/yield, and even the biological activity of the extracted oil [27].

SFME is a novel method that combines dry distillation with microwave heating at atmospheric pressure to isolate and concentrate essential oils and volatiles from plant material [54].

The purge and trap technique is a solvent-less extraction method with a high extraction efficiency though it was first developed for water and soil concentration of analytes [59]. The purge and trap technique was compared with simultaneous distillation extraction to analyze volatiles from Citrus sudachi [53].

The duration of distillation for complete extraction of essential oil is varied; for example, 3 hours [60-62], 4 hours [4,63-66], 5 hours [3], and 6 hours [42] depending on the interest of the analyst. Many factors may affect the quantity and quality of essential oil. Such factors include the method of extraction, temperature, time of extraction and distillation, and the analytical procedure of the phytochemical components of the essential oil. Apart from the technical and mechanical factors of the extraction procedure, the biological and physical condition of the plant may also contribute to the differences in the quality and quantity of essential oil. For instance, there is an effect on the quantity and quality of some essential oil components concerning distillation time [57,67].

It is also worth mentioning that essential oil chemical composition and yield can be affected by the maturity of the parts of the plant being investigated, especially leaves and fruit [68]. Some researchers [69] observed significant differences in the essential oil components of berries of Juniperus oxycedrus L. ssp. oxycedrus at different maturity stages; the same type of variation in chemical composition regarding maturity was also reported for essential oil from peppermint leaves [70]. Other factors affecting the quality and quantity of essential oils are soil composition and climate change [52].

The relevance of essential oils to conventional medicine cannot be overemphasized. Their usefulness is mirrored in different activities such as analgesic, anticancer, antiinflammatory, antimicrobial, antioxidative, wound healing, sedative, allelopathic, spasmolytic [7,71-74]. One of the most recent applications of essential oils in medicine is their use in regenerative medicine, drug delivery, and tackling drug resistance by the combination of essential oils with known antibiotics [75-80]. For example, the reconstruction of tissue damage following the resection of bone cancer by using composite materials made from collagen and hydroxyapatite mixed with eugenol acetate (a derivative of eugenol, which is a common constituent of essential oils). In this research, the researchers reported that the release of eugenol acetate is consistent such that its behavior suggests that it can be used in drug delivery systems with potential application as fillers in the orthopedic field in bone cancer treatment [80]. Majorly, the studies show how essential oils can be introduced in damaged tissue, either as bioactive compounds in bone fillers [79] or by encapsulating the essential oils in the drug 
delivery system, which could enhance the activity of the essential oils since they are highly volatile [78]. In the design of a drug delivery system, it is important to get the appropriate platform to convey the essential oil-bearing anticancer, anti-inflammatory, or anti-microbial properties to the desired site of action to ensure its release [81].

Also, with respect to the antibiotic action of some essential oils in dealing with multidrug resistant bacteria, several reports attest to the synergistic effects of the combination of essential oils with antibiotics, e.g., the synergistic effect of tea tree essential oil with oxacillin as observed in its action against Multi-resistant staphylococcus aureus (MSRA)[75]; and the synergistic effect of peppermint, cinnamon bark and lavender essential oils with piperacillin employed in it use against Escherichia coli [77].

Essential oils composition, functional groups present in active constituents, and their synergistic interactions are factors that determine the activity of essential oils [82,83]. It is important to note that the antimicrobial property or, in a more general term, the bioactivity of a given essential oil may depend only on one or two of the major constituents of the oil. Furthermore, it is imperative also to know that the interactions between the major and minor constituents are also of utmost importance and that the inherent activity of a particular essential oil may also depend on the ratio of the constituents [26].

According to the literature, many compounds have been identified in different essential oils of different plants; these compounds have been grouped and are presented in Table 1. The biological activities of the different classes of these compounds are also shown.

\subsection{Phytochemical components in the essential oil of some of the Ficus plants.}

\subsubsection{Ficus asperifolia.}

Ficus asperifolia is a small tree, sometimes average-sized. It is considered tellurian or epiphytal, measuring to a height of $20 \mathrm{~m}$. Native to Nigeria, Cameroon, Tanzania, South Africa, Senegal, Madagascar, and Uganda, Ficus asperifolia though ubiquitous in the savannah regions, is situated at an altitude of up to $1100 \mathrm{~m}$, especially in marshy areas and along river banks [101]. The ethanol and hot water extracts of the roots of Ficus asperifolia consist of saponins, alkaloids, glycosides, tannins, and flavonoids. Saponins and alkaloids were also reported in the aqueous root extract of Ficus asperifolia [102]. It was also observed that the extract showed strong inhibition of the bacteria $S$. pneumoniae showing its bactericidal property [103] with a $30.17 \mathrm{~mm}$ zone of inhibition which compared favorably with the antibiotic gentamycin used in the study with a $29.17 \mathrm{~mm}$ zone of inhibition. The plant is also known for its antioxidative property [101]. Using hydro distillation and the use of gas chromatography as well as gas chromatography-mass spectrometry(GC-MS), information pertaining to the major compounds present in the leaves of Ficus asperifolia and their percentage compositions were found to be; myristicin (16.4\%), limonene (15.7\%), Phytol (11.1\%), methyl salicylate (10.8\%) and cyclododecane (9.9\%) [104]. The authors also investigated the oil against Bacillus subtilis, Staphylococcus aureus, Escherichia coli, Kiebsiella spp., Proteus spp., Pseudomonas spp., Salmonella spp., Penicillium notatum, and Rhizopus stolonifera. The minimum inhibition concentrations ranged between $0.16-10 \mathrm{mg} / \mathrm{ml}$; the oil had the highest activity against Rhizopus stolonifera and the least activity to Pseudomonas spp. Table 2 shows the presence of compounds like myristicin, limonene, phytol, and methyl salicylate in abundance, all of which have been reported to show the antimicrobial property [16,105-108]. The antimicrobial property of this oil should be expected because, 
according to Table 1, methyl salicylate an ester, limonene, a hydrocarbon both have antifungal and antibacterial properties.

As gotten from literature, myristicin, limonene, phytol, and linalool are odorous compounds $[50,109,110]$, and they are also present in the essential oil of this plant.

\subsubsection{Ficus benghalensis L.}

Ficus benghalensis L. is found in large quantities in tropical areas [115], native to a wide area in Asia [116]. Pharmacologically, extracts of Ficus benghalensis have been implicated in possessing various beneficial properties such as anti-rheumatic [115], antioxidant [115,117], hepatoprotective [118], antibacterial [22,119], anti-allergic [120], antiinflammatory, analgesic [121,122]. It was also recorded that a methanol extract of Ficus benghalensis protects against oxidative liver injury in rats [123]. Certain researchers [116] reported the acetylcholinesterase inhibition of the total methanol extract of Ficus benghalensis L leaves, the $\mathrm{IC}_{50}$ of $194.6 \mu \mathrm{g} / \mathrm{ml}$ of the methanol extract compared favorably with the drug "donepezil" which has an $\mathrm{IC}_{50}$ of $186.1 \mu \mathrm{g} / \mathrm{ml}$.

Information from the first report of the essential oils from Ficus benghalensis revealed 24 compounds present, responsible for $96.4 \%$ of the total oil content. $\alpha$-Cadinol, germacrene D-4-ol, $\gamma$-Cadinene, $\alpha$-Muurolene and $\beta$-Caryophyllene epoxide making up $25.1 \%, 14.9 \%$, $11.8 \%, 9.6 \%$, and $6.2 \%$ respectively constituted a majority of the oil [63]. Table 2 shows the compounds that make up the essential leaf oil of the plant, as determined by gas chromatography-mass spectrometry (GC-MS) and their percentage composition.

This oil's likely odorous compounds are $\alpha$-phellandrene, limonene, linalool, $\beta$ caryophyllene, and $\alpha$-cadinol. The researchers did not investigate the oil for any bioactivity, but one may try to infer its bioactivity based on the components of the oil. For instance, the oil could possess insecticidal potentials because of the high amount of germacrene-D-4-ol - a compound with reported repellant effectiveness against mosquitoes and known cytotoxic property $[124,125]$. Furthermore, the oil could also be investigated for the bioactivities listed for its odorous compounds, as listed in Table 3.

\subsubsection{Ficus benjamina.}

This species, many of which are found cultivated by man, is one of the diverse species of this genera. Ficus benjamina is a tropical plant like most Moraceae, considerably the most common and found in Northern Australia and South Asia [66]. Traditionally, the plant has been used to treat cancers, piles, leprosy, skin disorders, inflammation, and malaria[148]. Literature report [148] described the extraction of different parts (stem, roots, and leaves) of Ficus benjamina with methanol. The methanol extract was thereafter fractionated with different solvents (chloroform, ethyl acetate, n-hexane, and n-butanol). The extracts were further investigated for their antimicrobial activity against Aspergillus niger, Candida albicans, Escherichia coli, Pseudomonas aerugonosa, Bacillus cerus, and Bacillus subtilis; it was discovered that the n-butanol fraction of the leaves and roots performed well with low M.I.C. values in the range $0.7-1.5 \mathrm{mg} / \mathrm{ml}$ and $0.77-1.99 \mathrm{mg} / \mathrm{ml}$ respectively.

According to previous research, it was discovered that cyclosativene, $\alpha$-copanene, and $\beta$-ocimene made up the compounds with the highest abundance present in the oil [149]. Day and night samples of Ficus benjamina were analyzed differently, and a total of forty-seven and thirty-eight compounds were isolated, respectively [66]. Thus, begging the question, "why the 
discrepancy in the essential oil content of the two samples gotten?' This could be a result of the difference in plant activity during the day and night. $\alpha$-pinene, abietadiene, germacrene-D4 -ol, and cis- $\alpha$-bisabolene, representing $13.9 \%, 9.7 \%, 8.4 \%$, and $8.2 \%$, respectively, were the main compounds extracted. Also, isobornyl acetate $(5.0 \%)$ and abietatriene (4.9\%) were also present in sizeable quantities. Germacrene-D-4-ol (31.5\%), however, was the most prevalent in the night sample, followed by 1,10-di-epi-cubenol, hexahydrofarnesyl-acetone, E-geranyl acetone, and 1, 8-cineole with respective percentages of $8.8 \%, 8.3 \%, 6.2 \%, 5.5 \%$ and $4.2 \%$ [66].

The oil's probable odorous compounds should include $\alpha$-phellandrene, 1,8-cineole, caryophyllene oxide, $\beta$-caryophyllene, linalool, $\alpha$-Pinene, camphor, myrcene, carvacrol, transnerolidol, limonene, and p-Cymene. It is worthy of mentioning that 1,8-cineole is a well-known antibacterial agent [150]

The authors did not investigate the oil for any bioactivity. The probable odiferous compounds in the night sample are caryophyllene oxide and camphor, which has been previously reported in the literature to both have insecticidal properties as shown in Table 3 , coupled with a very high amount of germacrene D-4-ol (31.5\%), which have also been reported to have insecticidal properties[124].

In another report, 2-Pentanone, 9,12-Octadecadienoic acid, hexadecanoic acid, palmitic acid were present in the stem's essential oil, while the root essential oil had eight compounds: arsenous acid, methanamine, cyclopentanone, methyl-2-phenylindole, cyclopropaneoctanal, 9,12-octadecadienoic acid, hexadecanoic acid, palmitic acid [148]. Though the stem and root have some similar compounds in their essential oil, there are no such compounds in the essential oils of the leaves.

\subsubsection{Ficus capensis.}

Ficus capensis Thunb is also known as Ficus sur Forssk, varies in height, ranging from 4 to about 9 meters. Predominantly in Tropical Africa, as well as in South Africa of varying species, the tree is described as being low branched with a spherical crown. In Nigeria, it is called "opoto" by the Yoruba ethnic group, "akororo" by the Igbo, "uwaryara" in Hausa [151]. It is believed to have fetish attributes because it promotes increased crop yield and fertility $[3,60]$. Some features of the leaves of Ficus capensis are; elongated elliptic leaves or ovate, ranging between 7.5 to $15 \mathrm{~cm}$ in length and 5 to $10 \mathrm{~cm}$ in width, acute apex with diverse kinds of the base, somewhat leathery, dark green without epidermal hairs, and dentate, wavy or entire margin. Its fruits could be paired figs or lone figs [152].

Ficus capensis has been shown to be of great ethnomedicinal use, such as in the treatment of diarrhea, $100-400 \mathrm{mg} / \mathrm{kg}$ of aqueous extracts of the leaves delayed the onset of stooling in albino rats [152]. It was also reported to be antibacterial as its crude extract hindered the growing process of Shigella sp. and E. coli [153], with M.I.C. values ranging between 500$2000 \mu \mathrm{g} / \mathrm{ml}$. Also, its leaves seem to possess antimicrobial, anti-inflammation, and antioxidative action, and this was linked to the presence of phytochemicals such as flavonoids, tannins, phenolics, and anthocyanins [3]. Ficus capensis has been reported traditionally to have a blood-boosting effect. The effect of the aqueous leaf extract on biochemical parameters of phenylhydrazine-induced-anemic rats was studied by [151]. The researchers reported that at $200 \mathrm{mg} / \mathrm{kg}$, the aqueous leaf extract does not have any antagonistic effect on the biochemical parameters of the rats. 
The essential oil content of three parts (leaves, stem bark, and root bark) of this species was investigated. The essential oil from the leaves contains about 27 compounds which are the highest among the parts investigated; this was followed by that of the stem (16), while the roots have the least number of compounds (13). The major compounds in the leaves are $\alpha$-cadinol $(10.6 \%), \alpha$-pinene $(9.3 \%)$, geranyllinalool $(6.9 \%)$, n-tetradecane $(6.5 \%), \alpha$-humulene $(6.5 \%)$ and $\alpha$-ionone (6.4\%); the stem bark had n-hexadecanoic acid (33.3\%), $\alpha$-pinene $(12.2 \%)$, $\beta$ pinene $(8.9 \%), \alpha$-humulene $(4.7 \%)$ and limonene $(4.4 \%)$ as its major essential oil composition and the root bark contained $\alpha$-pinene (36.7\%), n-hexadecanoic acid (15.5\%), $\beta$-pinene (14.9\%), limonene (7.9\%) and m-cymene (5.8\%) [60]. Table 2 gives information on all the compounds present in the essential oil of the three parts of this plant. $\alpha$-pinene and limonene are the odiferous compounds common to the three parts of this plant; $(E)$ - $\beta$-caryophyllene is common to both the leaves and the root, $\alpha$-phellandrene is common to stem and root and isocaryophyllene is common to the leaves and stem. Nerolidol and $\alpha$-cadinol are exclusive to the leaves. The researchers also reported toxicity to brine shrimps for the essential oils gotten from the stem bark, leaves, and root bark of Ficus capensis Thunb; toxicity to brine shrimps is a significant test because it has been related to antibacterial, pesticidal, cytotoxic, and antitumor properties [154]. The $\mathrm{LC}_{50}$ for the essential oil from stem bark, root bark, and leaves are 43.11 $\mu \mathrm{g} / \mathrm{mL}, 39.40 \mu \mathrm{g} / \mathrm{mL}$, and $16.38 \mu \mathrm{g} / \mathrm{mL}$, respectively. The percent composition of hexadecanoic acid in the stem essential oil is the greatest (33.3\%), followed by that of root bark (15.5\%), while it was not detected in the leaf essential oil at all. The leaf oil has the lowest $\mathrm{LC}_{50}$ value, and comparing the value to that of the root and stem shows an increase in the $\mathrm{LC}_{50}$ value, which may be because of the presence of n-hexadecanoic acid, because the higher the percentage of hexadecanoic acid, the higher the $\mathrm{LC}_{50}$ value thus, it looks as if n-hexadecanoic acid reduced the toxicity level of the oil. n-Hexadecanoic acid has the highest percent composition among the constituents of the essential oil in the stem bark. It has been reported to exhibit antioxidant and anticancer [97], pesticidal [94,155], and anti-inflammatory properties[96]. The researchers also conducted an acetylcholinesterase enzyme assay, and Huperzine A was used as a positive control. The activity of the three essential oils against Acetyl cholinesterase enzyme compared favorably with that of Huperzine A; this activity against Acetyl cholinesterase could be linked to the presence of significant amounts of $\alpha$-pinene and $\beta$-pinene in oils [136,137]. The $\mathrm{IC}_{50}$ values are $14.65 \mu \mathrm{g} / \mathrm{mL}$ (leaf), $14.11 \mu \mathrm{g} / \mathrm{mL}$ (stem bark) and $11.22 \mu \mathrm{g} / \mathrm{mL}$ (root bark)) while that of Huperzine A is $7.23 \mu \mathrm{g} / \mathrm{mL}$.

Huperzine A, a compound isolated from a Chinese plant, has been implicated in the treatment of fever and improvement of memory. It is important to mention that the root bark has the lowest value of $\mathrm{IC}_{50}$, and the percentage abundance of $\alpha$-pinene and $\beta$-pinene is highest in the root bark, which can be seen from Table 2; comparing the $\mathrm{IC}_{50}$ of the stem and the leaves, the value of $\mathrm{IC}_{50}$ increased with decrease in the amount of $\alpha$-pinene and $\beta$-pinene. The authors inferred that the oil from Ficus capensis could be explored to treat conditions involving memory improvement such as Alzheimer's disease. However, there is a need to deduce the relationship between the observed activities and the constituents of the oils[60].

However, in another report [104], the number of compounds found in the essential leaf oil was just 8 ; limonene and $\beta$-ionone were the common compounds in both of these species of leaf essential oil. According to the literature, limonene is the only odorous compound among the constituents for the essential leaf oil reported by these researchers. The antimicrobial potential of the essential leaf oil of Ficus capensis was also investigated by the authors. The microorganisms used in their research were Bacillus subtilis, Staphylococcus aureus, 
Escherichia coli, Kiebsiella spp., Proteus spp., Pseudomonas spp., Salmonella spp., Penicillium notatum, and Rhizopus stolonifera with M.I.C. values ranging from $0.08-10 \mathrm{mg} / \mathrm{ml}$. The oil was reported to be active against all the microorganisms except Kiebsiella spp. Overview of the bioactivity of Ficus capensis is presented in Table 4.

\subsubsection{Ficus carica.}

Ficus carica L, a transitory plant, is commonly known as "fig". The common fig is said to be one of the first-ever cultivated plants by man and is found mostly in the Eastern Mediterranean and Southwest Asia. It is consumed both in its fresh and dry form and is widely sought after as an important product in the world [23]. Ficus carica L. consisting of over 1400 species, is grouped into about 40 genera [23,156]. Species of Ficus carica consist of small trees or shrubs, whose roots are not adventitious with barks slightly rough [23]. Ficus carica has been used traditionally for its medical purposes, which include; metabolic, cardiovascular, and respiratory remedy [157], figs have also been reportedly used conventionally as a laxative [158], the fruit juice of Ficus carica mixed with honey is used for hemorrhage, inflammation, swellings, and tumors, it is often rubbed with the fruit paste to ease the pain [23]. The Methanol extract of the leaves of Ficus carica showed strong activities against S. anginosus, S. gordonii, P. intermedia, A. actinomycetemcomitans, and P. gingivalis [159]. Analysis of five Portuguese varieties of the leaves of Ficus carica was found to consist of diverse kinds of volatile compounds belonging to various chemical classes [14]. The latex of Ficus carica yielded the following essential oils: alkanals (octanal, heptanal, hexanal, pentanal, and benzaldehyde); alcohols (phenyl propyl alcohol, 1-butanol-2-methyl, 1-hexanol,1-pentanol, 1-heptanol, phenyl ethyl alcohol, and1-butanol-3-methyl); monoterpenes (cis-linalool oxide, epoxylinalool, eucalyptol, linalool, limonene, $\alpha$-pinene, $\beta$-pinene, $\alpha$-thujene, and terpinolene); sesquiterpenes (cadinene, germacrene $\mathrm{D}, \alpha$-guaiene, $\beta$-caryophyllene, trans- $\alpha$-bergamotene, $\alpha$-bourbonene, $\alpha$-calacorene-muuroleneand $\alpha$-caryophyllene); ketone (6-methyl-5-hepten-2-one) [17].

The components and percentage composition of the various volatile constituents of the leaves of Ficus carica grown in Egypt as determined by gas chromatography-mass spectrometry(GC-MS) were found to contain higher amounts in terms of percentages of (Z)-3hexenyl benzoate making up $19.8 \%$, n-tetracosane with $11.6 \%$, n-hexadecanoic acid constituting $9.2 \%$, n-docosane $(7.7 \%),(E)$-2-hexenal with $7.2 \%$, phytol $(6.7 \%)$ and nnonanal having $3.9 \%$ [111] is shown in Table 2. The latex and the leaves of this plant, however, contain hexanal, octanal, $\alpha$-pinene as similar components, which means there could be similarities in the essential oil components of different parts of a plant with probable different percentage compositions. $\alpha$-pinene, 1,8-cineole, (E)- $\beta$-caryophyllene, and phytol are some of the likely odorous constituents of this oil.

\subsubsection{Ficus elasticoidies De Wild.}

The essential oil of Ficus elasticoidies De wild, which is one of the more than 44 species of the Ficus genera found in Nigeria [160] analyzed by G.C. and GC-MS, revealed the constituents present. The high content compounds in this species of Ficus are; (E)-phytol (20.9 $\%), 6,10,14$-trimethyl-2-pentadecanone (8.7\%), and $\beta$-carophyllene (6.8 \%), 28 compounds totaling $76.5 \%$ of the oil were identified in the essential oil [64]. The compounds in the essential leaf oil of Ficus elasticoidies alongside their percentage composition is shown in Table 2. $\alpha$ - 
pinene, limonene, linalool, $\beta$-caryophyllene, caryophyllene oxide, and $(E)$-phytol should be the odorous constituents of this oil.

\subsubsection{Ficus exasperata Vahl.}

Ficus exasperata Vahl is one of the nearly 1000 species of Ficus plants found worldwide. It is a terrestrial afro-tropical small tree with scabrous, ovate leaves that grows up to about $20 \mathrm{~m}$ in height, being found in secondary forest and evergreen areas [160]. In India, it is commonly known as Brahma's banyan, rough banyan, and "sandpaper" fig, sandpaper owing to its rough leaf surface [161]. The phytochemical investigations of this species showed the presence of terpenoids, saponins, tannins, cardiac glycosides, and flavonoids, while alkaloids and anthraquinones were absent [162]. The leaves of Ficus exasperata have been known to be used in the treatment of many ailments. For example, in Nigeria, the leaves are used as an antipyretic [163], it was also shown to have anti-inflammatory properties [164], the leaves have also been analyzed for their hypoglycemic and hypolipidemic potential, thus, strengthening its use by Nigerians in the treatment of diabetes [165], the leaves are highly valued in treating malaria as a native Cameroonian medicine [166], in some parts of Cameroon, it is used to treat hemorrhoids [167], and the water extract is administered orally in the treatment of diarrhea in some other places [168]. The leaves of Ficus exasperata have been identified to possess bactericidal properties, being that its ethanol extract showed great inhibitory activity against $E$. coli and S. albus [169]. The volatile leaf oil constituents of Ficus exasperata have also been analyzed, and it was discovered that the oil is comprised of terpenoids and aliphatic compounds. The compounds making up most of the volume of the oil are 1,8-cineole (13.8\%), (E)-phytol (13.7\%), and p-cymene (11.4\%) [112]. Odorous compounds in the essential leaf oil of this plant should include 1,8-cineole, $(E)$-phytol, $p$-cymene, caryophyllene oxide, $\beta$ caryophyllene, and $\alpha$-pinene.

The leaf oil was reported to be inactive as an antibacterial since it has a M.I.C. of 625 ppm for all the tested microorganisms (Bacillus cereus, Staphylococcus aureus, and Pseudomonas aeruginosa). One would expect better activity from this oil since phytol has been reported to inhibit Staphylococcus aureus and Pseudomonas aeruginosa [128]. Though, according to Table 1, cymene is an antibacterial compound, although it has been reported to be an ineffective antibacterial compound [82,170,171]. The inactive nature of the oil could also be due to a lack of synergy between the components of the oil or because of the presence of cyclooctasulfur, a compound that is a rare constituent of essential oils.

The volatile oil component of the root back of Ficus exasperata has also been analyzed, and its major compounds are; $\alpha$-terpineol (33.7\%), $\alpha$-pinene $(10.8 \%)$, sabinene $(5.6 \%)$, and $\beta$ patchoulene (4.7\%), which is probably identified for the first time in Ficus exasperata oils [18]. The volatile compounds present in the root bark oil of Ficus exasperata and percentage constitution is shown in Table 2. $\alpha$-pinene, $\beta$-pinene, limonene, 1,8-cineole, linalool, geranyl acetate, $\beta$-caryophyllene, isocaryophyllene, $\alpha$-phellandrene, $\beta$-mycrene, caryophyllene oxide are compounds expected to be odorous in this oil. Table 4 shows the bioactivity of the extracted essential oil. The essential oil obtained from the root bark of Ficus exasperata was investigated for anti-candidal activity. The researchers reported that the oil showed a significant zone of inhibition, and a $1.1 \mu \mathrm{g} / \mathrm{mL}$ was recorded as the minimum inhibitory concentration (M.I.C.). The authors concluded that the oil has antifungal potential because the current drug of choice, amphotericin B, as at the time of their research for the treatment of C.albicans has a minimum inhibition concentration of $0.39 \mu \mathrm{g} / \mathrm{mL}$. Though the reason for the observed activity with 
regards to the composition of the oil was not explained by the researchers, it could be a result of the major compounds as well as minor compounds in the oil. Table 2 shows $\alpha$-Pinene as the second-highest compound by composition in the oil, and it has also been reported to be highly effective against yeast which is a known fungus [172]. The oil also contains a considerable amount of esters such as $\alpha$-frenchyl acetate $(1.1 \%)$, geranyl acetate $(1.0 \%)$, which according to Table 1, are considered as antifungal agents amongst other things; furthermore, the oil also contains a considerable amount of linalool which has been reported to have antifungal activity [173]. In addition, according to Table 3 , geranyl acetate, 1,8-cineole, $\beta$-caryophyllene, and caryophyllene oxide are also antifungal agents. Phellandrene, limonene, sabinene, and $\alpha$ pinene are presented in Table 1 as compounds with antibacterial properties. According to Table 2 , they are present in reasonable quantities in the root bark oil means the root bark oil could also be an excellent antibacterial agent.

\subsubsection{Ficus lutea Vahl.}

This species, synonymous with Ficus vogelii (Miq.), is a rubber-producing tree in West Africa, doing so in varying quantities as it rapidly grows. Its bark and leaves are red in color. A report [174] described the leaves to possess anti-diabetic properties; acetone was used to extract from the leaves, after which the acetone extract was fractionated with different solvents: water, ethylacetate, hexane, n-butanol, dichloromethane, and chloroform. The ethylacetate fraction had a considerable antidiabetic activity at $250 \mu \mathrm{g} / \mathrm{ml}$ when compared with glibenclamide that was used as a positive control, and exhibited anti-diabetic activity at 50 $\mu \mathrm{g} / \mathrm{ml}$.

Having been judiciously analyzed, acorenone B (20.7\%), followed by phytol (16.2\%), demethoxyageratochromene $(6.0 \%), 6,10,14$ trimethyl-2-pentadecanone $(5.1 \%)$, and zingiberene (5.2\%) made up the most abundant components in the volatile oil of the leaves [113]. The percentage composition of the various compounds found in the essential leaf oil of Ficus lutea can be seen in Table 2. It can be seen from Table 2 that acorenone is the most abundant compound in this oil; this compound has been reported to inhibit acetylcholinesterases and butyrylcholinesterase, which have been related to Alzheimer's disease [137] therefore, the oil could be investigated for the inhibition of both enzymes. Some odorous compounds in this oil are $\alpha$-pinene, $\beta$-caryophyllene, caryophyllene oxide, and phytol. The oil could also be effective against fungi because of the presence of $\alpha$-pinene, $\beta$ caryophyllene, and caryophyllene oxide.

\subsubsection{Ficus mucoso Welw.}

The leaves and fruits of Ficus mucoso Welw. are edible; they are used to treat medical cases such as leprosy, insanity, and edemas [4]. Oils from the leaves were obtained via hydrodistillation, and its constituents were determined using GC-MS, and of 35 isolates, $\alpha-$ phellandrene, $p$-cymene, germacrene $\mathrm{D}, \beta$-caryophyllene, 1,8-cineole and $\alpha$-copaene with percentages of $13.0 \%, 11.3 \%, 10.5 \%, 9.7 \%, 9.5 \%$, and $8.7 \%$ respectively made up the constituents in abundance [4]. The oil comprises the following odorous constituents $p$-cymene, 1,8-cineole, $\alpha$-phellandrene, $\alpha$-pinene, and $\alpha$-cadinol.

The antimicrobial activity of the essential leaf oil of Ficus mucoso was also investigated, as shown in Table 4, the oil was tested against Bacillus cereus, Staphylococcus aureus, Escherichia coli, Pseudomonas aeruginosa, Candida albicans, and Aspergillus niger, 
the oil was found to show greater potency against Aspergillus niger with a M.I.C. value of 78 $\mu \mathrm{g} / \mathrm{ml}$ [4]. From Table 2, it can be seen that $p$-cymene (11.3\%) is the major constituent of F.mucoso oil. This compound has been reported to be an ineffective antimicrobial compound, especially alone $[82,170,171]$. This could be the reason F.mucoso oil was only active towards Aspergillus niger, or it could be that the synergy between all the components of the oil can only affect Aspergillus niger. The cytotoxic effect of Ficus mucoso leaf essential oil and was also investigated. The Ficus mисоso oil displayed a strong inhibitory effect against human Hs578T breast ductal carcinoma cells with a $98.18 \%$ kill at $250 \mu \mathrm{g} / \mathrm{mL}$; however, the oil has no significant effect on human PC-3 prostatic carcinoma cells. The authors attributed the observed activity towards human Hs578T breast ductal carcinoma to the constituents of Ficus mucoso oil; from Table 2, it is obvious that Ficus mucoso oil comprises majorly sesquiterpenes such as $\beta$-caryophyllene and germacrene $\mathrm{D}$, in which these compounds have been previously reported to show cytotoxic activity $[72,125]$.

\subsubsection{Ficus natalensis subsp. leprieurii.}

Ficus natalensis subsp. leprieurii is also one of the abundant species of Ficus genera found in Nigeria. Traditionally it is used in medicine in inducing lactation and as a cure for influenza [64]. The stem bark of this plant possesses antimicrobial properties, and the methanol extract had a M.I.C. value of $0.625 \mathrm{mg} / \mathrm{ml}$ against Pseudomonas aeruginosa [175]. The components of the essential oil of the leaves of Ficus natalensis were extracted by hydrodistillation and analyzed. 24 compounds representing $78.3 \%$ of the oils were identified, and the main constituents in Ficus natalensis subsp. leprieurii essential oil were (E)-phytol having $37.6 \%$ and 6,10,14-trimethyl-2-pentadecanone with $24.9 \%$ [64]. Table 2 shows the compounds present in the volatile oil of Ficus natalensis subsp. leprieurii leaves and their percentage composition. The leaf oil of this plant contains the following $(E)$-phytol, $\alpha$-pinene, limonene, linalool, $\beta$-caryophyllene, and caryophyllene oxide as odorous compounds.

\subsubsection{Ficus ovata Vahl.}

Ficus ovata is also one of the myriads of Ficus species found in relatively abundant quantities in Nigeria. The stem bark has been reported for its antimicrobial property; a M.I.C. value of $39 \mu \mathrm{g} / \mathrm{ml}$ was recorded against Staphylococcus aureus. [176]. The volatile leaf oil of this plant has been analyzed, and 23 compounds making $71.4 \%$ of the oil were established using G.C. and GC-MS. Of the 23 compounds identified, $(E)$-phytol (24.5\%), hexadecanoic acid, $(10.0 \%)$ caryophyllene oxide $(7.6 \%)$ and 6,10,14-trimethyl-2-pentadecanone $(6.1 \%)$ were in high proportion. Also, a significant amount of geranyl acetone (4.5\%) and $\beta$-ionone (3.1\%) were found in Ficus ovata leaf oil [64]. $\alpha$-Pinene, benzaldehyde, linalool, $\beta$ caryophyllene, limonene, (E)-Phytol, and caryophyllene oxide are the likely odorous compounds in this oil.

\subsubsection{Ficus polita.}

Ficus polita Vahl, a huge tree towering a height of 10 to 16 meters, is native to coastal forests and evergreen forests. Locally given the name 'Durumi' by the Hausas and 'Rita' by the Kanuris in Nigeria [113,177]. 
Table 1. Different classes of essential oils compounds and their bioactivities.

\begin{tabular}{|c|c|c|c|}
\hline Class of compounds & Examples & Known Bioactivities & References \\
\hline Hydrocarbons & $\begin{array}{c}\text { Phellandrene, cymene, pinene, mycrene, sabinene, } \\
\text { germacrene D limonene. }\end{array}$ & $\begin{array}{c}\text { Decongestant, antibacterial, hepatoprotective, antiviral, } \\
\text { antitumor, stimulant }\end{array}$ & {$[16,37,40,44,84-88]$} \\
\hline Esters & $\begin{array}{c}\text { Linalyl acetate, bornyl acetate, eugenol acetate, } \\
\text { geranyl acetate. }\end{array}$ & $\begin{array}{c}\text { Anti-inflammatory, antifungal, spasmolytic, } \\
\text { anaesthetic, sedative. }\end{array}$ & {$[37,88-93]$} \\
\hline Acids & $\begin{array}{l}\text { Hexadecanoic acid, octadecanoic acid, } \\
\text { tetradecanoic acid. }\end{array}$ & Anti-inflammatory, antioxidant, repellant, emulsifying & [94-97] \\
\hline Oxides & $\begin{array}{c}\text { Bisabolone oxide, sclareol oxide, linalool oxide, } \\
\text { ascaridole carophyllene oxide. }\end{array}$ & Expectorant, stimulant, anti-inflammatory. & {$[37,88,92,93]$} \\
\hline Lactones & $\begin{array}{c}\text { Costuslactone, nepetalactone, } \\
\text { dihydronepetalactone, alantrolactone, bergaptene. }\end{array}$ & $\begin{array}{l}\text { Antiviral, sedative, antipyretic, antimicrobial, } \\
\text { analgesic, hypotensive. }\end{array}$ & {$[37,88,93,98,99]$} \\
\hline Alcohols & $\begin{array}{l}\text { Citronellol, geraniol, borneol, linalool, citronellol, } \\
\text { menthol, Germacrene D-4-ol, nerol. }\end{array}$ & $\begin{array}{c}\text { Balancing, anaesthetic, spasmolytic, tonifying, anti- } \\
\text { inflammatory, antiseptic. }\end{array}$ & {$[37,88,90-93]$} \\
\hline Phenols & Carvacrol, thymol, chavicol, eugenol. & $\begin{array}{l}\text { Spasmolytic, anaesthetic, immune stimulating, irritant, } \\
\text { antimicrobial. }\end{array}$ & {$[37,88,92,93]$} \\
\hline Aldehydes & $\begin{array}{l}\text { Cinnamaldehyde, citral, benzaldehyde, } \\
\text { cuminaldehyde, myrtenal, citronellal. }\end{array}$ & $\begin{array}{l}\text { Calming, antiviral, antipyretic, tonic, sedative, } \\
\text { vasodilators, spasmolytic, hypotensive, antimicrobial. }\end{array}$ & {$[37,82,88]$} \\
\hline Ketones & $\begin{array}{l}\text { Thujone, menthone, verbenone. fenchone, carvone, } \\
\text { pulegone, camphor. }\end{array}$ & $\begin{array}{l}\text { Antiviral, spasmolytic, sedative, mucolytic, neurotoxic, } \\
\text { digestive, cell regenerating, analgesic. }\end{array}$ & {$[37,88,89,93,100]$} \\
\hline
\end{tabular}

Table 2. The essential oil composition of the 14 Ficus species under review.

Species

F. asperifolia

F. Benghalensis

F. benjamina

\section{Compounds contained}

Myristicin (16.4\%), limonene (15.7\%), phytol (11.1\%), methyl salicyclate (10.8\%), cyclododecane (9.9\%), n-tricosane (4.2\%), terpinen-4-ol (3.6\%), (E)-2-nonenol (3.4\%), tetradecanal (2.5\%), safrole (2.5\%), methyl eugenol (2.4\%), 6.10dimethyl-2-undecanone(1.9\%), (E)-B-ionone (1.9\%), geranyl acetone $(1.7 \%),(Z, Z)$-farnesylacetone (1.6\%), 2-ethyl hexyl acetate $(1.5 \%)$, Z-methyl isoeugenol $(1.3 \%),(E, E)$ - $\alpha$-farnesene $(1.2 \%)$, linalool $(1.2 \%)$, viridiflorol $(1.0 \%)$ and elemicin $(0.8 \%)$. Total $(96.6 \%)$

$\alpha$-cadinol (25.1\%), germacrene D-4-ol (14.9\%), $\gamma$-cadinene $(11.8 \%), \alpha$-muurolene $(9.6 \%), \beta$-Caryophyllene epoxide $(6.2 \%)$, cyclosativene $(4.7 \%)$, cubenol $(4.1 \%), \tau$-cadinol $(3.8 \%),(\mathrm{E})-\beta$-Ionone $(2.2 \%), \delta$-Cadinene $(2.0 \%), \beta$ - Geranylacetone $(1.8 \%)$, Toluene (1.7\%), $\gamma$-Muurolene (1.1\%), ethylbenzene (1.1\%), $\alpha$-copaene (1.0\%), $\alpha$-phellandrene $(1.0 \%)$, linalool $(1.0 \%), \beta$ caryophyllene $(0.8 \%)$, maaliene $(0.7 \%)$, n-nonanal $(0.5 \%)$, n-hexanal $(0.4 \%), \beta$-cyclocitral $(0.3 \%),(\mathrm{E})$ - $\alpha$-ionone $(0.3 \%)$ and limonene (0.3\%). Total (96.4\%).

\section{Day Sample}

$\alpha$-pinene $(13.9 \%)$, abietadiene $(9.7 \%)$, germacrene D-4-ol $(8.4 \%)$, cis- $\alpha$-bisabolene $(8.2 \%)$, isobornyl acetate $(5.0 \%)$, abietatriene $(4.9 \%)$, sabinene $(3.7 \%)$, 4-terpineol $(2.5 \%)$, trans-pinocarveol $(2.5 \%)$, myrtenal $(2.4 \%)$, verbenone $(2.2 \%), \rho-$ Mentha-1,5-dien-8-ol (2.1\%),1,8-cineole (2.1\%), dehydro-p-cymene (2.0\%), limonene (2.0\%), Dipropyl trisulfide (1.5\%), $\alpha$-campholenal (1.4\%), dipropyl disulfide (1.2\%), p-cymene (1.2\%), (E)-geranyl acetone $(1.2 \%)$, hexahydrofarnesylacetone $(1.2 \%)$, camphor $(1.2 \%)$, pinocarvone $(1.2 \%)$, camphene $(1.1 \%), \beta$-caryophyllene $(0.9 \%)$, thuja- $2,4(10)$-diene $(0.8 \%),(\mathrm{E})$ - $\beta$ farnesene $(0.8 \%)$, myrcene $(0.8 \%)$, inalool $(0.8 \%), \alpha$-phellandrene $(0.7 \%), \beta$-cyclocitral $(0.5 \%)$, cis-linalool oxide (furanoid) $(0.3 \%), 1,10$-di-epi-Cubenol $(0.3 \%)$, trans-Carveol $(0.2 \%)$, $\delta$-cadinene $(0.2 \%)$, methyl carvacrol $(0.2 \%)$, (E)- $\alpha$-ionone $(0.2 \%)$, $\rho$-cymen-8-ol $(0.2 \%)$, benzaldehyde $(0.1 \%), \alpha$-terpinene $(0.1 \%), \gamma$-terpinene $(0.1 \%), \delta$-3-carene (trace), 3,7 -dimethyl-2,6octadienal (trace), nonanal (trace), safranal (trace), carvone (trace). Total $(\mathbf{9 0 . 0 \%})$

$$
8015
$$

\begin{tabular}{|l|c} 
Part of plant & References \\
\hline Leaves & {$[104]$} \\
\hline Leaves & {$[63]$} \\
\hline & \\
\hline Leaves & {$[66]$} \\
& \\
&
\end{tabular}


Species

F. carica

F. elasticoidies
Compounds contained

Night Sample:

Germacrene D-4-ol (31.5\%), 1,10-di-epi-cubenol (8.8\%), hexahydrofarnesylacetone (8.3\%), (E)-geranyl acetone $(6.3 \%)$, cubenol (5.5\%), 1,8-cineole (4.2\%), caryophyllene oxide (2.6\%), $\beta$-caryophyllene (2.3\%), linalool (1.6\%), $\beta$-bisabolene $(1.6 \%)$, (E)- $\beta$-ionone $(1.5 \%)$, isoborneol $(1.4 \%),(\mathrm{E})$ - $\alpha$-ionone $(1.3 \%)$, nonanal $(1.3 \%), \alpha$-pinene $(1.2 \%)$, camphor $(1.2 \%)$, pentadecanal $(1.2 \%)$,isobornyl acetate $(1.0 \%)$, (E)-2-hexenal $(0.9 \%)$, safranal $(0.9 \%), \beta$-cyclocitral $(0.8 \%)$, $\beta$-pinene $(0.6 \%)$, myrcene $(0.6 \%)$, carvacrol $(0.6 \%)$, trans-nerolidol $(0.5 \%)(\mathrm{E})-\beta$-damascone $(0.5 \%)$, undecanal $(0.5 \%)$, phenylacetaldehyde $(0.5 \%)$, 6-methyl-5-hepten-2-one ( $0.5 \%), \alpha$-terpineol $(0.4 \%)$, camphene $(0.4 \%)$, benzaldehyde $(0.4 \%)$, limonene $(0.4 \%)$, nhexadecane $(0.3 \%), 9$-epi-(E)-caryophyllene $(0.2 \%), \alpha$-copaene (trace), $\delta$-cadinene(trace), p-cymene (trace). Total $(\mathbf{9 1 . 0 \%})$

\section{Leaves:}

$\alpha$-cadinol (10.6\%), $\alpha$-pinene (9.3\%), geranyllinalool (6.9\%), $\alpha$-humulene (6.5\%), n-tetradecane(6.5\%), $\alpha$-ionone $(6.4 \%), \beta$ pinene $(4.5 \%)$, caryophyllene oxide $3.9 \%)$, spathulenol (3.7\%), isocaryophyllene (3.4\%), E-nerolidol (3.1\%), limonene $(3.1 \%), \quad(\mathrm{Z})$-ocimenone $(2.8 \%)$, germacrene $(2.4 \%)$, m-cymene $(2.1 \%), \gamma$-terpinene $(2.0 \%)$, n-tridecane $(1.9 \%),(\mathrm{E})-\beta$ caryophyllene $(1.8 \%)$, neophytadiene, Isomer III $(1.4 \%)$, 3E,7E-4,8,12-trimethyltri deca-1,3,7,11-tetraene $(1.3 \%), \delta$ amorphene $(1.2 \%)$, geranylacetone $(1.1 \%)$, safranal $(1.1 \%), \beta$-ionone $(1.0 \%)$, neophytadiene, Isomer I $(0.9 \%)$, neophytadiene, Isomer II $(0.8 \%), \gamma$-humulene $(0.7 \%)$,. Total $(\mathbf{9 0 . 4 \%})$

\section{Stem:}

n-hexadecanoic acid (33.3\%), $\alpha$-pinene $(12.2 \%), \beta$-pinene $(8.9 \%), \alpha$-humulene $(4.7 \%)$, limonene $(4.4 \%)$, pentadecanoic acid $(4.0 \%), \gamma$-terpinene $(3.7 \%)$, n-tetradecanoic acid $(2.1 \%)$, erpinolene $(1.9 \%)$, camphene $(1.6 \%)$, p-cymene $(1.5 \%),(\mathrm{E})$ $\alpha$-bergamotene $(1.3 \%)$, cyperene $(1.0 \%), \alpha$-phellandrene $(0.8 \%)$ isocaryophyllene $(0.5 \%), \alpha$-thujene $(0.2 \%)$. Total $(82.1 \%)$ Roots:

$\alpha$-pinene (36.7\%), $\mathrm{n}$-hexadecanoic acid (15.5\%), $\beta$-pinene (14.9\%), limonene (7.9\%), m-cymene (5.8\%), $\gamma$-terpinene $(4.1 \%)$ (E)- $\beta$-caryophyllene (3.6\%), $\alpha$-humulene (3.2\%), $\alpha$-phellandrene (1.8\%), neophytadiene, Isomer I $(1.2 \%), \alpha$-thujene $(0.7 \%)$, camphene $(0.5 \%)$, terpinolene $(0.1 \%)$. Total $(\mathbf{9 6 . 0 \%})$

\section{Leaves:}

n-tricosane $(52.2 \%)$, n-hexacosane $(24.2 \%)$, cyclotetradecane $(15.4 \%)$, triacontane $(3.3 \%)$, limonene $(2.8 \%)$, trans geranylgeraniol $(0.7 \%)$, n-hexadecanoic acid $(0.6 \%),(\mathrm{E})$ - $\beta$-ionone $(0.5 \%)$. Total $(\mathbf{9 9 . 7 \%})$

(Z)-3-hexenyl benzoate (19.8\%), n-tetracosane (C-24) (11.6\%), n-hexadecanoic acid $(9.2 \%)$, n-Docosane (C-22) (7.7\%), (E)2-Hexenal (7.2\%), phytol (6.7\%), n-nonanal (3.9\%), n-pentacosane (C-25) (1.9\%), n-heneicosane (C-21) (1.5\%) (E,E)- $\alpha$ farnesene $(1.3 \%), 6,10,14$-trimethylpentadecan-2-one $(1.3 \%)$, cis-muurola-4(15),5-diene $(1.2 \%)$, n-heptadecane $(1.0 \%)$, nonadecane $(0.9 \%)$, phytane $(0.9 \%)$, heptacosane $(0.8 \%)$, n-octadecane $(0.8 \%)$, $\beta$-ionone $(0.8 \%)$, n-tetradecanoic acid $(0.8 \%)$, (E)- $\beta$-damascenone $(0.7 \%)$, farnesane $(0.6 \%), \alpha$-Pinene $(0.6 \%)$, nerylacetone $(0.6 \%)$, methyl salicylate $(0.6 \%), 1$-octanol $(0.5 \%)$, pentadecane $(0.5 \%)$, dillether $(0.5 \%)$, cis-eudesma-6,11-diene $(0.4 \%), \mathrm{n}-8(\mathrm{E})$-2,6-dimethylocta-1,5,7-trien-3-o $(0.4 \%)$, Non-1-en-3-ol $(0.4 \%)$, dodecanal $(0.4 \%)$, myrtenal $(0.4 \%)$, 3-thujene-10-al $(0.4 \%)$, 4-isopropylcyclohexanol (Isomer 2) $(0.4 \%)$, ethyl benzoate $(0.3 \%)$, n-octanal $(0.3 \%)$, ethyl hexadecanoate $(0.2 \%), 1,8$-Cineol $(0.2 \%)$, methyl palmitate $(0.2 \%)$, (E)- $\beta$-caryophyllene $(0.2 \%)$, spathulenol $(0.1 \%)$,viridiflorol $(0.1 \%), 7,11$-dimethylheptadecane $(0.1 \%)$, neophytadiene (Isomer 2) $(0.1 \%)$. Total $(\mathbf{8 8 . 5 \%})$.

(E)-Phytol (20.9\%), geranyl acetone (9.4\%), 6,10,14-trimethyl-2-pentadecanone (8.7\%), $\beta$-carophyllene (6.8\%), $\alpha$-Ionone $(4.5 \%)$, octacosane $(2.5 \%), \beta$-Ionone $(2.4 \%)$, hexadecanoic acid $(2.0 \%)$, oleic acid $(2.0 \%)$, carophylleneoxide $(2.0 \%)$, benzaldehyde (1.6\%), $\beta$-selinene (1.5\%), heptacosane (1.4\%), 6-Methyl-5-hepten-2-one (1.3\%), octadecanoic acid $(1.3 \%)$, (E)-9-octadecenoic acid, ethyl ester (1.0\%), limonene (0.9\%), 1-Octen-3-ol (0.9\%), 2-dimethoxy-4-ethyl-benzene (0.9\%), nnonanal $(0.8 \%)$, $\alpha$-pinene $(0.8 \%), 3,4$-dimethyl toluene $(0.7 \%)$, 2-Hexen-1-ol benzoate $(0.4 \%)$, isophytol $(0.4 \%)$, linaloo $(0.4 \%),($ E)-Menth-2-en-1-ol (0.4\%), Z-Menth-2-en-1-ol (0.3\%), neral (0.3\%),

Total $(\mathbf{7 6 . 5 \%})$

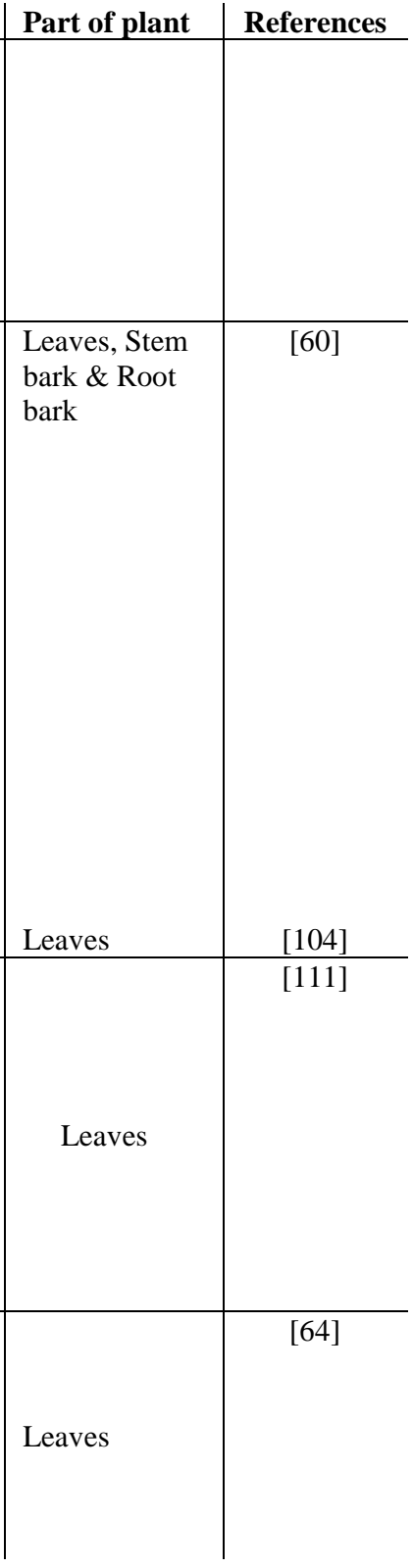


Species

F. exasperate

Ficus lutea

Ficus natalensis subsp. leprieurii

Ficus ovata

Ficus polita
Compounds contained

Root Bark: $\alpha$-Terpineol (33.7\%), $\alpha$-pinene (10.8\%), sabinene (5.6\%), $\beta$-patchoulene (4.7\%), $\beta$-pinene (3.2\%), limonene $(3.1 \%), 1,8$-cineole $(3.1 \%)$, linalool $(2.8 \%)$, $\alpha$-thujopsene $(2.1 \%),(E)$ - $\beta$-Ocimene $(1.7 \%), \alpha$-Terpinene $(1.7 \%), \beta$-bisabolene $(1.5 \%), \alpha$-Copaene $(1.4 \%)$, allo-Aromadendrene $(1.3 \%),(Z)$ - $\beta$-Ocimene $(1.2 \%), \alpha$-Frenchyl acetate $(1.1 \%)$, geranyl acetate $(1.0 \%), \beta$-caryophyllene $(1.0 \%)$, cedrol $(0.8 \%), 2$-Carene $(0.8 \%)$, isocaryophyllene $(0.8 \%), \alpha$-phellandrene $(0.8 \%), \beta$ mycrene $(0.7 \%)$, caryophyllene oxide $(0.5 \%)$, globulol $(0.5 \%)$, aromadendrene $(0.5 \%)$, guaiol $(0.5 \%),(E)-\beta$-Farnesene $(0.4 \%), \alpha$-Thujene $(0.4 \%)$, ledol $(0.4 \%)$, carotol $(0.3 \%), \mathrm{D}$ - $\beta$-cyclocitral $(0.3 \%),(\mathrm{E}, \mathrm{E})-\alpha$-farnesene $(0.3 \%), \delta$-cadinene $(0.3 \%), \beta$-selinene $(0.3 \%), \alpha$-cubebene $(0.3 \%), \alpha$-ylangene $(0.3 \%)$, verbenone $(0.2 \%), \beta$-copaene $(0.2 \%), \beta$-cubebene $(0.2 \%)$ bornyl acetate $(0.2 \%)$, dotriacontane $(0.2 \%)$, germacrene $\mathrm{D}(0.2 \%), \alpha$-humulene $(0.2 \%), \alpha$-selinene $(0.1 \%),(Z)$-3-hexenyl acetate $(<0.1 \%)$, undecanal $(<0.1 \%)$, cecanal $(<0.1 \%)$, tetradecane $(<0.1 \%)$, benzaldehyde $(<0.1 \%)$, (E.E)-2,6-dimethyl1,3,5,7-cyclooctateraene $(<0.1 \%)$, benzyl alcohol $(<0.1 \%)$, 4-methyl benzaldehyde $(<0.1 \%)$, methyl benzoate $(<0.1 \%)$, methyl salicyclate $(<0.1 \%)$. Total $(\mathbf{9 1 . 8 \%})$.

Leaves: 1,8-cineole (13.8\%), $(E)$-phytol (13.7\%), p-cymene (11.4\%), $\beta$-ionone (7.5\%), 6,10,14-trimethyl-2-pentadecanone (7.0\%), cyclooctasulfur $(6.1 \%)$, caryophyllene oxide $(5.4 \%), \beta$-caryophyllene $(4.3 \%)$, neryl acetone $(4.2 \%), \alpha$-ionone $(2.9 \%), \alpha$-Pinene $(2.2 \%)$, 9-octadecanoic acid $(2.9 \%)$, Total $(\mathbf{8 5 . 7 \%})$.

Acorenone B (20.7\%), phytol (16.2\%), demethoxyageratochromene (6.0\%), zingiberene (5.2\%), $6,10,14$-trimethyl -2pentadecanone $(5.1 \%)$, caryophyllene oxide $(4.4 \%), \beta$-caryophyllene $(4.3 \%)$, farnesyl acetone $(4.0 \%)$, valencene $(3.4 \%)$, (E,E)- $\alpha$-farnesene (3.2\%), $\gamma$-cadinene (2.5\%), $\alpha$-selinene (2.4\%), $\beta$-sesquiphellandrene (2.3\%), $\beta$-bisabolene (1.9\%), (E)- $\beta$ ionone $(1.7 \%)$, himachalene (1.6\%), $\alpha$-humulene $(1.4 \%), \alpha$-pinene $(1.3 \%)$, drimenol $(1.2 \%)$, (E)- $\alpha$-ionone $(1.1 \%)$, hexadecanal $(0.9 \%), 1,3,5$-trimethylbenzene $(0.9 \%)$,benzaldehyde $(0.7 \%), \beta$-pinene $(0.7 \%), \quad \alpha$-copaene $(0.4 \%)$, ethyl linoleolate $(0.3 \%)$. Total $(\mathbf{9 3 . 8 \%})$.

$\alpha$-Phellandrene (13.0\%), $p$-cymene (11.3\%), germacrene D (10.5\%), $\beta$-caryophyllene (9.7\%), 1,8-Cineole (9.5\%), $\alpha$-copaen $(8.7 \%)$, terpinolene $(4.9 \%), \alpha$-humulene $(3.5 \%)$, (3Z)-hexenol $(3.4 \%),(E)$-3-methyl-non-2-en-4-one $(3.0 \%)$, linalool $(2.1 \%)$, alloaromadendrene $(2.0 \%), \delta$-cadinene $(1.8 \%)$, spathulenol $(1.7 \%)$, dill Apiole $(1.6 \%), \beta$-Ionone $(1.6 \%)$, muurolene $(1.3 \%),(3 Z)$-hexenyl benzoate $(1.3 \%)$, methyl salicylate $(1.2 \%), \beta$-cyclocitral $(1.0 \%)$, carotol $(0.9 \%)$, safranal $(0.7 \%), \alpha$ terpineol $(0.6 \%), \alpha$-cubebene $(0.6 \%), \alpha$-ionone $(0.6 \%), \alpha$-pinene $(0.5 \%),(E)$-Nerolidol $(0.5 \%)$, bicyclogermacrene $(0.5 \%), \alpha-$ Cadinol $(0.5 \%)$, cubebene $(0.4 \%), \tau$-cadinol $(0.3 \%), \beta$-elemene $(0.3 \%), \alpha$ - $(E, E)$ - $\alpha$-farnesene $(0.2 \%), \beta$ - $\alpha$-gurjunene $(0.2 \%)$ $\gamma$-muurolene $(0.2 \%)$, .Total $(\mathbf{1 0 0} \%)$.

(E)-Phytol (37.6\%),6,10,14-trimethyl-2-pentadecanone (24.9\%), geranyl acetone (2.8\%), hexadecanoic acid $(2.0 \%)$ carophyllene oxide $(1.7 \%)$, oleic acid $(1.6 \%), \beta$-ionone $(1.2 \%)$, octacosane $(1.1 \%), \alpha$-ionone $(0.9 \%), \beta$-carophyllene $(0.7 \%)$, heptacosane $(0.6 \%)$, neral $(0.5 \%)$,octadecanoic acid $(0.5 \%)$, benzaldehyde $(0.3 \%)$, $(E)$-menth-2-en-1-ol $(0.3 \%)$, limonene $(0.3 \%)$, n-nonanal $(0.2 \%)$, Z-menth-2-en-1-ol $(0.2 \%)$, 1-octen-3-ol $(0.2 \%)$, isophytol $(0.2 \%), 6$-methyl-5-hepten-2-one $(0.2 \%)$, linalool $(0.1 \%), 3,4$-dimethyl toluene $(0.1 \%), \quad \alpha$-pinene $(0.1 \%)$. Total (78.3\%).

(E)-Phytol (24.5\%), hexadecanoic acid (10.0\%),carophyllene oxide (7.6\%), 6,10,14-trimethyl-2-pentadecanone $(6.1 \%)$ geranyl acetone $(4.5 \%), \beta$-ionone $(3.1 \%)$, linalool $(2.3 \%)$, $\beta$-carophyllene $(2.2 \%)$, n-nonanal $(2.0 \%)$, octacosane $(1.9 \%)$ octadecanoic acid (1.4\%), heptacosane $(1.2 \%)$, oleic acid $(1.1 \%)$, isophytol $(0.8 \%)$, benzyl tiglate $(0.7 \%)$, $\alpha$-ionone $(0.6 \%)$, 6-methyl-5-hepten-2-one $(0.4 \%)$, limonene $(0.3 \%)$, benzyl benzoate $(0.3 \%), . \alpha$-pinene $(0.1 \%)$, benzaldehyde $(0.1 \%), 2$ Dimethoxy-4-ethyl-benzene (0.1\%), 1-Octen-3-ol (0.1\%), Total (71.4\%)

Phytol (23.3\%), $6,10,14$-trimethyl-2-pentadecanone (15.0\%), (E)-6,10-dimethyl -5,9- undecadien-2-one (7.3\%), drimeno $(5.8 \%)$, (E)- $\beta$-ionone $(4.1 \%)$, caryophyllene oxide $(4.0 \%)$, farnesyl acetone $(3.7 \%), \beta$-selinene $(2.0 \%),(\mathrm{E})$ - $\alpha$-ionone $(1.9 \%)$ hexadecanal $(1.7 \%)$, acorenone B $(1.4 \%), \beta$-caryophyllene $(1.3 \%)$, zingiberene $(1.2 \%)$, (E,E) spathulenol $(1.0 \%), 2,4$ decadienal $(1.0 \%)$, phenanthrene $(0.9 \%)$, p-menth-4-en-3-one $(0.8 \%)$,heptacosane $(0.8 \%), 6$, 10,14-trimethyl-2pentadecanol $(0.7 \%)$, isocaryophyllene oxide $(0.6 \%)$,dihydro- $\beta$-ionone $(0.6 \%)$, epi-globulol $(0.6 \%)$, safranal $(0.6 \%)$, 2 pentylfuran $(0.5 \%), 1,3,5$-trimethylbenzene $(0.5 \%)$, p-cymene $(0.5 \%)$, fluoranthene $(0.5 \%)$, caryophyllene alcohol $(0.4 \%)$,
Part of plant

Root bark

References

[18]

[112]

Leaves

Leaves

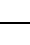

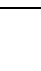

Leaves

Leaves


Species

Ficus religiosa

Ficus thonningii
Compounds contained

a-copaen-8-ol $(0.4 \%)$, demethoxyageratochromene $(0.4 \%)$, benzaldehyde $(0.4 \%)$, salvial-4(14)-en-1-one (0.3\%),6-methyl5-hepten-2-one $(0.3 \%), \beta$-cyclocitral $(0.3 \%)$, methyl hexadecanoate $(0.3 \%)$, cadalene $(0.2 \%)$, isophytol $(0.2 \%)$, nonana $(0.2 \%), \alpha$-pinene $(0.1 \%)$. Total $(\mathbf{8 5 . 8 \%})$.

Eugenol (27.6\%), itaconic anhydride (15.4\%),3-methylcyclopenetane-1,2-dione (10.8\%), 2-phenylethyl alcohol $(8.0 \%)$, benzyl alcohol $(4.2 \%)$, allyl caproate $(3.5 \%)$, coumaran $(3.4 \%), \beta$-eudesmol $(1.8 \%)$, unidentified $(1.7 \%),(E)$ - $\beta$-ionone $(1.6 \%)$, salicylaldehyde $(1.5 \%)$, benzeneacetonitrile $(1.2 \%),(3 Z)$-hexenol $(1.1 \%)$, catechol $(1.1 \%), p$-vinylguaiacol $(1.1 \%), \alpha-$ eudesmol (1.0\%), epi- $\alpha$-cadinol (1.0\%), unidentified $(0.8 \%)$, (2Z)-hexenol $(0.7 \%)$, pentadecanal $(0.7 \%)$, phenol $(0.7 \%)$, phytol $(0.7 \%)$, unidentified $(0.7 \%)$, n-hexanol $(0.7 \%)$, palmitic acid $(0.7 \%), \alpha$-cadinol $(0.7 \%)$, adipoin $(0.6 \%),(E)$-cinnamy alcohol $(0.6 \%)$, (3Z)-hexenyl tiglate $(0.6 \%)$, phenylacetaldehyde $(0.6 \%)$, (3Z)-hexenyl benzoate $(0.5 \%)$, epi- $\gamma$-eudesmol $(0.5 \%),(E)$-linalool oxide $(0.5 \%)$, (2E,6Z)-nonadienol $(0.5 \%)$, (2E)-nonen-1-ol $(0.5 \%)$, (2E,6Z)-nonadienal $(0.4 \%)$, dihydroactinidiolide $(0.4 \%), \alpha$-copaene-11-ol $(0.4 \%), \gamma$-eudesmol $(0.4 \%),(2 E)$-hexenyl $(3 Z)$-hexenoate $(0.3 \%)$, linalool $(0.3 \%), n$-nonanal $(0.3 \%)$. Total $(\mathbf{9 7 . 2 \% )}$.

6 ,10,14-trimethyl-2-pentadecanone (18.8\%), phytol (14.7\%), acorenone B (7.6\%), $\beta$-gurjunene (6.3\%), o-xylene $(4.6 \%)$,caryophyllene oxide $(3.7 \%)$, zingiberene $(3.4 \%)$, (E)- $\alpha$-ionone $(2.9 \%)$,octadecanal $(2.9 \%)$, $\alpha$-eudesmol $(2.3 \%)$, (E)6,10-dimethyl -5,9- undecadien-2-one (2.1\%), (E)- $\beta$-ionone (1.9\%), benzaldehyde (1.7\%), arnesyl acetone (1.5\%), isophytol $(1.5 \%), 1,3,5$-trimethylbenzene $(1.5 \%)$, p-xylene $(1.4 \%)$, $\beta$-eudesmol $(1.3 \%)$, p-menth-4-en-3-one $(1.3 \%)$, hexanal $(1.2 \%)$, $\beta$-caryophyllene $(1.2 \%)$, acetophenone (1.1\%), 2-pentylfuran $(1.0 \%)$, cyclosativene $(0.9 \%)$, $\beta$-pinene $(0.9 \%)$, fethyl benzene $(0.8 \%)$, phenylacetaldehyde $(0.8 \%), \alpha$-pinene $(0.7 \%), 6$-methyl-5-hepten-2-one $(0.7 \%), \beta$-cyclocitral $(0.5 \%), \alpha$-copaene $(0.5 \%)$, elemol $(0.5 \%)$,. Total $(\mathbf{9 2 . 2 \%})$.

\begin{tabular}{|l|c} 
Part of plant & References \\
\hline Leaves & \\
\hline & \\
\hline Leaves & \\
\hline & \\
&
\end{tabular}

Table 3. Odorous compounds in the essential oils.

\begin{tabular}{|c|c|c|c|}
\hline Odorous compounds & Odour type & Bioactivity & References \\
\hline Limonene & Turpentine like & Antioxidant, anticancer & {$[126,127]$} \\
\hline Phytol & Floral & Antibacterial, antiinflammatory & {$[128,129]$} \\
\hline 1,8-cineole & Herbal & Antifungal, anti-inflammatory, analgesic & [130] \\
\hline$\alpha$-humulene & Woody & Anti-inflammatory, analgesic, anticancer & {$[126,127]$} \\
\hline$\beta$-carophyllene & Woody & Antifungicidal, antibacterial, antioxidant, antiproliferative & {$[72,131]$} \\
\hline Carophyllene oxide & Woody & $\begin{array}{c}\text { Antifungal, insecticidal } \\
\end{array}$ & [132] \\
\hline Linalool & Floral & Antimicrobial, analgesic, antioxidant & {$[26,127,133]$} \\
\hline Eugenol & Spicy & Antimicrobial & {$[26,127]$} \\
\hline Thymol & Herbal & Antimicrobial, antioxidant & {$[16,26,127]$} \\
\hline$\alpha$-terpinene & Lemon & Antioxidant & {$[127]$} \\
\hline p-cymene & Citrus & Antimicrobial, anti-inflammatory, anticancer, antioxidant & {$[26,132,134]$} \\
\hline$\alpha$-pinene and $\beta$-pinene & Herbal & Antibacterial, acetylCholinesterase & {$[132,135-137]$} \\
\hline Nerolidol & Floral & Antimalarial, antileishmanial & [132] \\
\hline$\alpha$-cardinol & Herbal & Antifungal & [138] \\
\hline Myrcene & Balsamic & Analgesic, sedative, antiinflammatory & {$[126]$} \\
\hline Geraniol & Floral & Antimicrobial & {$[26]$} \\
\hline Myristicin & Spicy warm balsamic woody & Anticancer & {$[127]$} \\
\hline$\alpha$-Phellandrene & Terpenic & Cholinesterase inhibition, antifungal & {$[139,140]$} \\
\hline Camphor & Camphoraceous & Antibacterial, insecticidal, antiviral, & {$[127,141]$} \\
\hline Carvacrol & Oregano like & Antibacterial, antioxidant & {$[127]$} \\
\hline
\end{tabular}




\begin{tabular}{c|c|c|c} 
Odorous compounds & Odour type & Bioactivity & References \\
\hline bicyclogermacrene & Balsamic & Cytotoxic & {$[142]$} \\
\hline$\alpha$-copaene & Spicy & Antioxidant & {$[143]$} \\
\hline Nonanal & Citrus & Antifungal & Antifungal, antioxidant \\
\hline terpinolene & Herbal & Anti-inflammatory and antifungal & Antifungal \\
\hline Geranyl acetate & Floral & Antimicrobial and anti-inflammatory & {$[145]$} \\
\hline phenylacetaldehyde & Floral & {$[146]$} &
\end{tabular}

Table 4. Bioactivity of the essential oil of some of the Ficus species under review.

\begin{tabular}{|c|c|c|c|}
\hline Species & Bioactivity & Part of Plant & References \\
\hline F.exasperata & Anti-candidal & Roots & [18] \\
\hline F. тисово & Cytotoxic, anti-microbial & Leaves & [4] \\
\hline F. capensis & Acetyl cholinesterase inhibitory activity & Leaves, stem bark and root bark & [60] \\
\hline F. capensis & Antimicrobial & Leaves & {$[104]$} \\
\hline F. religiosa & $\begin{array}{c}\text { Cytotoxic } \\
\text { anti-bacterial against } \\
\text { Aspergillus niger }\end{array}$ & Leaves & {$[114]$} \\
\hline Ficus asperfolia & Antimicrobial & Leaves & [104] \\
\hline
\end{tabular}


This tree is known to hold medicinal properties such as anti-inflammatory; the dichloromethane extracts compare favorably with indomethacin; the anti-inflammatory activity was investigated by using the TPA-induced mouse ear edema; the edema reduced by $65 \%$ after the first hour and by $75 \%$ after the second hour [178]. The chloroform leaf extract of Ficus polita has been reported to rectify oxidative stress as well as possess hypolipidaemic activity [179].

Its ethanol extracts have also been shown to possess anti-malarial is as they inhibit the growth of plasmodium falciparum with an $\mathrm{IC}_{50}$ value of $20.8 \mu \mathrm{g} / \mathrm{ml}$ [180]; thus, it could be used as an alternative anti-malarial drug for people who are unable to purchase the modern drugs. The major components of the leaf essential oil of this tree with respect to the percentage composition are; $23.3 \%$ phytol, $15.0 \%$ of $6,10,14$-trimethyl-2-pentadecanone, $7.3 \%$ (E)-6, 10dimethyl-5, 9-undecadien-2-one, and drimenol making up 5.8\% [113]. The information on the available compounds in this plant's leaf essential oil and their percentage abundance is given in Table 2.

\subsubsection{Ficus religiosa Linn.}

Ficus religiosa Linn is a very big tree of this species, ranging from $150 \mathrm{~m}$ to $1550 \mathrm{~m}$ in height, commonly referred to as 'Peepal tree' by the Hindus, is a widely branched tree and is said to be one of the oldest and sacred trees in their myth. [114,181]. Traditionally, Ficus religiosa is an aphrodisiac plant, which prompted [182] to investigate the plant's aqueous dry and fresh leaf extracts to cure polycystic ovary syndrome (PCOS) in rats model. The researchers documented that the fresh leaf extract in particular directly alleviates the steroid imbalances with the regular orchestrated estrous cycle in letrozole-administered PCOSinduced rats, which suggests that the leaf extract has the potential to cure PCOS.

Ficus religiosa is also a plant of known antimicrobial activity, as the aqueous extract showed high antimicrobial activity against Bacillus subtilis and Pseudomonas aeruginosa making it useful as a multi-resistant drug [183], at $500 \mu \mathrm{g} / \mathrm{ml}, 70 \%$ aqueous-ethanol extracts hindered Helicobacter pylori growth, and this was observed across all strains [184]. The fruit of Ficus religiosa is known to contain many compounds beneficial to humanity, including but not limited to amino acids, sesquiterpenes, alcohols, aldehydes, ketones, etc. [185]. Ficus religiosa also has other properties, including anti-inflammatory and analgesic activity [186]. The essential oil content of the leaves of Ficus religiosa was analyzed. It was discovered that a total of 44 peaks were identified, making up $97.2 \%$ of the oil and eugenol (27.0\%), itaconic anhydride (15.4\%), 3-methyl cyclopentane-1,2-dione (10.8\%), 2-phenyl ethyl alcohol (8.0\%). Benzyl alcohol (4.2\%) were the compounds with the highest quantities [114].

The compounds present in the oil are listed in Table 2, with about 3 compounds unidentified. The essential oil from the leaves of Ficus religiosa was inactive to C.albicans alongside organisms such as Pseudomonas aeruginosa, Bacillus cereus, Staphylococcus aureus, and Escherichia coli though the oil was reported to be slightly active towards Aspergillus niger with a minimum inhibitory concentration of $625 \mu \mathrm{g} / \mathrm{mL}[114]$. Table 2 shows that Eugenol is the main constituent of the leaf essential oil (27.6\%). Table 1 listed eugenol as one of the phenols in an essential oil that exhibits antimicrobial properties, Table 3 also listed it as an antimicrobial agent. Several reports also show that eugenol is effective as an antimicrobial compound [26]; therefore, one would expect a good antimicrobial property for the oil. The inactive nature of the oil could be as a result of no synergistic interaction between eugenol and other constituents of the essential oil or because other constituents that have 
antimicrobial activity are too small to exert moderate activity, for example, cinnamyl alcohol and $\alpha$-eudesmol, which have also been reported to have antimicrobial property is just $0.6 \%$ and $1.0 \%$ respectively in the oil as shown in Table $2[11,187]$. Though, the oil showed in vitro cytotoxic activity against MCF-7 human breast tumor cell line with $80 \pm 5 \%$ kill at $100 \mu \mathrm{g} / \mathrm{mL}$. This could be due to the presence of $\alpha$-eudesmol, which has been reported to produce a cytotoxic effect in human hepatocellular carcinoma [132]. In addition to the in vitro cytotoxic activity, the oil was also slightly active in the brine shrimp lethality test with an $\mathrm{LC}_{50}$ of 50 $\mu \mathrm{g} / \mathrm{mL}$. The probable odorous compounds in this oil are linalool, phenol, phytol $(0.7 \%)$, eugenol, and $\alpha$-cadinol.

\subsubsection{Ficus thonningii.}

Ficus thonningii Blume is commonly known as "strangler fig", and is common to riverine, upland forest, and rocky areas; this fig is also found in Nigeria [113]. The tree's bark embeds in it many medicinal uses, such as its use in treating colds, diarrhea, constipation, and stimulating lactation [188]. Methanol, ethyl acetate, and chloroform were used to extract the leaves of this plant. Of the three solvents, the ethyl acetate had the highest antimicrobial activity; the wound healing property of the ethyl acetate extract was also documented. The evaluation of wound contraction after post wounding days is close to what was observed for gentamicin, the drug used as the positive control [189]. The hydro-ethanol extract of the stem bark of Ficus thonnigii was reported to contain flavonoids, saponins, quinones, alkaloids, coumarins, catechic tannins, polyphenols, flavonoids, phlebotanins, and Antho cyanides; the extracts at $500 \mathrm{mg} / \mathrm{kg}$ were able to increase Catalase activity, glutathione and superoxide dismutase while inhibiting xanthine oxidase, malondialdehyde and pepsin concentration which led the authors to conclude that the extract has a promising therapeutic and pharmacologic activity for the management of ulcers [190].

The essential oil composition was determined by gas chromatography-mass spectrometry, and the following were found to be in high quantity: 6,10,14-trimethyl-2pentadecanone (18.8\%), phytol (14.7\%), acorenone B (7.6\%), and $\beta$-gurjunene (6.3\%) [113]. Table 2 below shows the compounds present in the essential leaf oil of Ficus thonningii and their percentage composition. The presence of a high amount of phytol could mean that the oil might be useful in the cosmetics industry. Acorenone is also another abundant compound in this oil, and this compound has been reported to inhibit acetylcholinesterases and butyrylcholinesteras related to Alzheimer's disease [137]. Table 2 shows the constituents of the essential oils of different Ficus species alongside their percent abundance arranged in decreasing order.

\section{Application of Compounds Found in the Essential Oil of the Plants under Review}

The Ficus plants reviewed revealed a high content of the following compounds (some of these compounds are said to be biomarkers of Nigeria Figs): Phytol, Germacrene D-4-ol, $\alpha$ Pinene, $\alpha$-Humulene, Hexadecanoic acid, 6,10,14-trimethyl-2-pentadecanone, $\beta$-pinene, $\alpha$ cadinol, $p$-cymene, $\alpha$-copaene, carophyllene oxide, and $\beta$-carophyllene. Information on the application of these compounds will help infer the probable application of the essential oil that contains them. Some compounds have also been known to play important roles in various industries like food, pharmaceutical, and cosmetics. 


\section{1. (E)-phytol.}

Having stated earlier that $(E)$-phytol is one of the markers of essential oil obtained from Nigerian Ficus species, we would look briefly into some of its uses and applications. Phytol is also known as 3, 7, 11, 15-tetramethyl-2-hexadecen-1-ol and is an isoprenoid component found in chlorophyll [191]. Phytol, acyclic diterpene alcohol, is used as a precursor to producing vitamin E, K1, and some other tocopherols [192-194]. It is also believed to be the most abundant acyclic isoprenoid compound present in the biosphere, and the products of its degradation are used as biogeochemical tracers in aquatic environments [195]. One of the uses of phytol is seen in its application in the cosmetic industries, in the production of soaps and detergents, largely due to its inviting fragrance [129]. This follows the information presented in Table 1 that alcohols as essential oils are used as antiseptics. Phytol can be used in the food industry to preserve foods susceptible to bacterial infection due to its ability to inhibit the growth of some bacteria like Pseudomonas aeruginosa and Staphylococcus aureus [128].

Some of the medical applications of this diterpene alcohol are seen in its ability to; act as an anti-inflammatory response drug as it was seen to reduce cytokine levels, neutrophil migration, and oxidative stress in models of acute inflammation [196]; alcohols as components of essential oils have been reported to be useful as an anesthetics and as an anti-inflammatory agent as presented in Table 1. It has also been used to treat Schistosomiasis in humans, as it was seen to reduce the worm load in a mouse infected with Schistosomiasis mansoni [194]. Although phytol is a natural product, it can be synthesized in the laboratory from acetone [197].

\section{2. $\alpha$-Pinene.}

$\alpha$-Pinene is bicyclic monoterpene [132] which is found in most of the Ficus species discussed in this review has myriads of medical usefulness. $\alpha$-Pinene is made up of two enantiomers, the (-)- $\alpha$-pinene and (+)- $\alpha$-pinene, of which the positive enantiomer was found to possess antimicrobial activity [135]. It is known to have high potency as an anti-bacterial agent [16], although it's highly effective against yeasts and a group of bacteria classified as Gram-positive [132,172]. $\alpha$-Pinene's ability to work against bacteria is by inducing toxicity on the membrane structure, thus hampering the function of the membrane [198], and Table 1 presents pinene as one of the hydrocarbons in essential oils with antibacterial and antiviral as some of the potential activities.

A research carried out showed that $\alpha$-pinene is capable of inhibiting leukocyte migration which is necessary in an inflammatory response and, as such, can be used to treat cases with high leukocyte migration [199]. $\alpha$-pinene has also been seen to show the antinociceptive property [200]. Furthermore, pinene has been reported to inhibit the Acetyl cholinesterase enzyme [136,137], an enzyme that has been deemed important in treating Alzheimer's disease.

\subsection{Other compounds.}

n-Hexadecanoic acid, a constituent of essential oil from the Ficus plant, is known to be used as a pesticide, as well as an antioxidant [97,155]. It is also implicated in an antiinflammatory role, as it showed inhibitory activity in the enzyme kinetics of Phospholipase A2 [96]. 
Cymene is one of the compounds that fall under the hydrocarbon class of compounds in essential oils, as presented in Table 1. Among the biological properties of the hydrocarbon class in Table 1 is a decongestant. P-cymene medicinally is used to eradicate phlegm and prevent cough [134].

Germacrene-D, is known for its insecticidal property, as it is seen to be effective against mosquitoes [124]. It has also been found to possess cytotoxic attributes [125].

$\beta$-Caryophyllene, a volatile bicyclic sesquiterpene lactone compound [201] found in some of the Ficus species reviewed, has shown both anti-fungicidal and anti-bactericidal actions [72,131]. $\beta$ - caryophyllene was also exhibited selective anti-proliferative effects against colorectal cancer cells and powerful antioxidant effects [72]. It is also added to foods as a preservative [202]. Due to its fine fragrance and safe use, it is added to cosmetics [203]. The therapeutic effects of $\beta$-caryophyllene in pain and inflammation, neurodegenerative diseases, gastrointestinal disorders, and many others have also been identified, and as a result of its safety when consumed, it has been used as a marker for quality control in some industries where it is widely used [201].

\subsection{Odorous compounds in essential oils.}

Extraction of essential oil is often followed by its analysis; most times, the essential oil is subjected to gas chromatography/mass spectrometry (GC/MS) and gas chromatography/ (GC/FID) for its characterization. One of the characteristics of essential oil is its odor (aroma) which is based on its components [83]. The essential oil can contain more than one odorous compound. The odor of a particular essential oil may be as a result of a large amount of a single compound, or in some others, trace elements are also important when it comes to essential oil odor, and that is why there is no easy overview when it comes to the major odorants in essential oils [110]. Often times the true odor is a manifestation of a complex mix of compounds. Knowing the odor of essential oil could be necessary in case imitation is required because of the scarce nature of essential oils [110]. Generally, the odor of essential oils can be classified into groups such as woody, herbaceous, minty, floral, spicy, camphorous, and earthy [83]. There are different techniques used in the determination of odor of essential oils, and the major one is the use of gas chromatography/olfactometry $(\mathrm{GC} / \mathrm{O})$; it could also be coupled with a mass spectrometer as GC-MS-O [50,110,204]. Odor intensity is ranked using CHARM analysis [110,205] and aroma extract dilution assay (AEDA) [110,206]; AEDA has proven to be better, and it can also be combined with stable isotopic dilution analysis (SIDA) [110,207] for another precise level of quantification.

The odor potency can be estimated using flavor dilution factor (FD); it is also possible to get the significant contribution of each odorant to the characteristic odor of the essential oil by getting the odor activity values (OAV) which is the ratio of the concentration to the odor threshold of the compound [50]. GC/O was used to identify the active odor compounds in the essential oil of Eurya japonica [109]. The active odor compounds were also identified in the essential oil of Magnolia obovata using GC/O and AEDA [50]. In this review, most of the analyses carried out on the essential oils of the Ficus species did not include the identification of odorous compounds. However, a list of previously confirmed odorous compounds gotten from literature and found in the essential oils of the Ficus species under review was presented in Table 3, alongside the bioactivities of these compounds. The bioactivities of the odorous compounds could give information on the probable potential of the oils that contain them. It is also worthy to note that the odor of a particular essential oil can also depend on the method by 
which the essential oil is extracted. For instance, the essential oil extracted from Magnolia obovata via hydrodistillation had a floral-sweet-spicy-woody odor, while the one extracted via Solvent assisted flavor evaporation (SAFE) had a spicy-woody-sweet-green odor [50].

\section{Conclusion and Future Prospects}

This review has pointed out that essential oils can be gotten from almost every part of the Ficus species and that there are diverse useful components in oils. There is a need to search for more bioactive compounds for the drug, food, and cosmetic industries. The following areas will need more attention.

The extraction of essential oils has been solely from leaves, as this review has pointed out. Extraction from other parts like root, stem can lead to more yield of essential oils. Attention also has to be given to extraction from fruits as this has received the least attention.

Other extraction methods ought to be investigated; this review has shown that the major extraction method has been hydrodistillation. Other methods may afford better yield as well as better quality.

Attention must also be paid to how method parameters such as distillation time, temperature, pressure, the time-lapse between extraction and analysis for the components affect the quality and quantity of essential oil.

The effect of maturity on the yield and chemical composition of essential oils from Ficus species, especially for the leaves and fruits, is also worthy of investigation.

There is also a need to investigate the quality and quantity of essential oil gotten from the plants related to how the sample is treated. In this review, essential oils were extracted majorly after air-drying the sample; essential oil quality and quantity of fresh samples and airdried samples can be compared, especially since they are extremely volatile.

In this review, most of the works reported are basically on the extraction of essential oils, with few reports on the bioactivity of the oils even though essential oils have been playing a major role in managing diverse disease conditions and infections for decades. There is a need for a dedicated study on the pharmacological properties of these oils with the cases of drug resistance and a new strain of disease-causing organism evolution every day.

Isolation of phytochemical compounds often leads to possible synthesis in the laboratory and on the industrial scale. For example, the isolation of penicillin and its effectiveness against fungi led to its synthesis in the laboratory and industrially. There is a need to isolate compounds from the essential oils extracted, which will lead to their possible synthesis for our drug, food, and cosmetic-related industries.

Figs generally are very important plants as their use can be seen in diverse areas, which are not limited to anti-bacterial, anti-diabetic, anti-malarial, anti-cancer. This review has pointed out that Ficus species can be classified as essential oil-bearing plants. The essential oil can be obtained from all parts of the plants as already presented. Generally, essential oil contains numerous compounds that have proven useful in the cosmetics, drug, and food industries. The essential oil components from Ficus species have also shown that their essential oil can be useful in the chemical industries. These compounds can be a pilot in the synthesis of myriads of compounds for use by humanity.

\section{Funding}

This research received no external funding. 


\section{Acknowledgments}

The authors would like to appreciate friends and colleagues who supported and encouraged us through the research and writing process, especially those who provided us with research materials at stages where we had difficulty accessing some of the literature.

\section{Conflicts of Interest}

The authors declare no conflict of interest.

\section{References}

1. Oktay, M.; Gülçin, I.; Küfrevioğlu, Ö.I. Determination of in Vitro Antioxidant Activity of Fennel (Foeniculum Vulgare) Seed Extracts. LWT-Food Sci. Technol. 2003, 36, 263-271, https://doi.org/10.1016/S0023-6438(02)00226-8.

2. Wangensteen, H.; Samuelsen, A.B.; Malterud, K.E. Antioxidant Activity in Extracts from Coriander. Food Chem. 2004, 88, 293-297, https://doi.org/10.1016/j.foodchem.2004.01.047.

3. Muanda, N.F.; Dicko, A.; Soulimani, R. Chemical Composition and Biological Activities of Ficus Capensis Leaves Extracts. J. Nat. Prod. 2010, 3, 147-160.

4. Essien, E.E.; Newby, J.M.; Walker, T.M.; Isiaka, A.; Setzer, W.N.; Ekundayo, O. Essential Oil Constituents, Anticancer and Antimicrobial Activity of Ficus Mucoso and Casuarina Equisetifolia Leaves. Am. J. Essent. Oils Nat. Prod. 2016, 4, 1-6.

5. Kebede, A.; Hayelom, M. The Design and Manufacturing of Essential Oil Distillation Plant for Rural Poverty Alleviation in Ethiopia. Ethiop. J. Environ. Stud. Manag. 2008, 1, 84-91, https://doi.org/10.4314/ejesm.v1i1.41573.

6. Ramadan, M.F. Nutritional Value and Applications of Nigella Sativa Essential Oil: A Mini Review. J. Essent. Oil Res. 2015, 27, 271-275. https://doi.org/10.1080/10412905.2015.1045564.

7. Franco, C.D.; Ferreira, O.O.; Antônio Barbosa de Moraes, Â.; Varela, E.L.; Nascimento, L.D.; Percário, S.; de Oliveira, M.S.; Andrade, E.H. Chemical Composition and Antioxidant Activity of Essential Oils from Eugenia patrisii Vahl, E. punicifolia (Kunth) DC., and Myrcia tomentosa (Aubl.) DC., Leaf of Family Myrtaceae. Molecules 2021, 26, https://doi.org/10.3390/molecules26113292.

8. Edris, A.E. Pharmaceutical and Therapeutic Potentials of Essential Oils and Their Individual Volatile Constituents: A Review. Phyther. Res. 2007, 21, 308-323, https://doi.org/10.1002/ptr.2072.

9. Kejlová, K.; Jírová, D.; Bendová, H.; Gajdoš, P.; Kolářová, H. Phototoxicity of Essential Oils Intended for Cosmetic Use. Toxicol. Vitr. 2010, 24, 2084-2089, https://doi.org/10.1016/j.tiv.2010.07.025.

10. Vankar, P.S. Essential Oils and Fragrances from Natural Sources. Resonance 2004, 9, 30-41, https://doi.org/10.1007/bf02834854.

11. Bakkali, F.; Averbeck, S.; Averbeck, D.; Idaomar, M. Biological Effects of Essential Oils - A Review. Food Chem. Toxicol. 2008, 46, 446-475, https://doi.org/10.1016/j.fct.2007.09.106.

12. Al-Matani, S.K.; Al-Wahaibi, R.N.S.; Hossain, M.A. Total Flavonoids Content and Antimicrobial Activity of Crude Extract from Leaves of Ficus Sycomorus Native to Sultanate of Oman. Karbala Int. J. Mod. Sci. 2015, 1, 166-171, https://doi.org/10.1016/j.kijoms.2015.11.007.

13. Semwal, A.; Kumar, R.; Vir, U.; Teotia, S.; Singh, R. Pharmacognostical Evaluation of Medicinally Important Ficus Retusa (Leaves and Bark). J. Acute Dis. 2013, 2, 300-303, https://doi.org/10.1016/S22216189(13)60148-1.

14. Oliveira, A.P.; Silva, L.R.; Guedes de Pinho, P.; Gil-Izquierdo, A.; Valentão, P.; Silva, B.M.; Pereira, J.A.; Andrade, P.B. Volatile Profiling of Ficus Carica Varieties by HS-SPME and GC-IT-MS. Food Chem. 2010, 123, 548-557, https://doi.org/10.1016/j.foodchem.2010.04.064.

15. Al-matani, S.K.; Al-wahaibi, R.N.S.; Hossain, M.A. In Vitro Evaluation of the Total Phenolic and Fl Avonoid Contents and the Antimicrobial and Cytotoxicity Activities of Crude Fruit Extracts with Different Polarities from Ficus Sycomorus. Pacific Sci. Rev. A Nat. Sci. Eng. 2016, 17, 103-108, https://doi.org/10.1016/j.psra.2016.02.002.

16. Nartey, D.; Gyesi, J. N.; Borquaye, L.S. Chemical Composition and Biological Activities of the Essential Oils of Chrysophyllum Albidum G. Don (African Star Apple). Biochem. Res. Int. 2021, 2021, 1-11, https://doi.org/10.1155/2021/9911713.

17. Badgujar, S.B.; Patel, V.V.; Bandivdekar, A.H.; Mahajan, R.T. Traditional Uses, Phytochemistry and Pharmacology of Ficus Carica: A Review. Pharm. Biol. 2014, 52, 1487-1503, https://doi.org/10.3109/13880209.2014.892515.

18. Oladosu, I.A.; Zubair, M.F.; Ali, M.S.; Olawore, N.O. Anticandidal Activity of Volatile Compounds from the Root Bark of Ficus exasperata Vahl-Holl (Moraceae). Journal of Essential Oil Bearing Plants 2009, 12, 562-568, https://doi.org/10.1080/0972060X.2009.10643758. 
19. David G. Frodin. History and Concepts of the Big Plant Genera. Taxon 2004, 53, 753-776.

20. Hamed, M.A. Beneficial Effect of Ficus Religiosa Linn. on High-Fat-Diet-Induced Hypercholesterolemia in Rats. Food Chem. 2011, 129, 162-170. https://doi.org/10.1016/j.foodchem.2011.04.066.

21. Ahmed, F.; Urooj, A. Traditional Uses, Medicinal Properties, and Phytopharmacology of Ficus Racemosa : A Review. Pharm. Biol. 2010, 48, 672-681, https://doi.org/10.3109/13880200903241861.

22. Salem, M. Z. M.; Salem, A. Z. M.; Camacho, L. M.; Ali, H. M. Antimicrobial Activities and Phytochemical Composition of Extracts of Ficus Species : An over View. African J. Microbiol. Res. 2013, 7, 4207-4219.

23. Mawa, S.; Husain, K.; Jantan, I. Ficus Carica L. (Moraceae): Phytochemistry, Traditional Uses and Biological Activities. Evidence-Based Complement. Altern. Med. 2013, 2013, https://doi.org/10.1155/2013/974256.

24. Rønsted, N.; Salvo, G.; Savolainen, V. Biogeographical and Phylogenetic Origins of African Fig Species (Ficus Section Galoglychia). Mol. Phylogenet. Evol. 2007, 43, 190-201, https://doi.org/10.1016/j.ympev.2006.12.010.

25. Singh, S.; Jain, S. K.; Alok, S.; Chanchal, D.; Rashi, S.; Pradesh, U. A Review on Ficus Religiosa- An Important Medicinal Plant. Int. J. Life Sci. Rev. 2016, 2, 1-11.

26. Chouhan, S.; Sharma, K.; Guleria, S. Antimicrobial Activity of Some Essential Oils — Present Status and Future Perspectives. Medicines 2017, 4, 1-21, https://doi.org/10.3390/medicines4030058.

27. Getahun, T.; Sharma, V.; Gupta, N. Chemical Composition and Biological Activity of Essential Oils from Aloe Debrana Roots. J. Essent. Oil-Bearing Plants 2020, 493-502, https://doi.org/10.1080/0972060X.2020.1788996.

28. Wei, T.; Zhu, M.; Zhou, J.; Chen, L.; Sheng, L.; Feng, L. Cytological Evidence for the Pathway of Synthesis, Accumulation, and Secretion of Rose Essential Oil. J. Essent. Oil-Bearing Plants 2019, 22, 301-310, https://doi.org/10.1080/0972060X.2019.1605938.

29. Ahmadi, L.; Mirza, M.; Shahmir, F. The Volatile Constituents of Artemisia Marschaliana Sprengel and Its Secretory Elements. Flavour Fragr. J. 2002, 17, 141-143, https://doi.org/10.1002/ffj.1055.

30. Bezić, N.; Šamanić, I.; Dunkić, V.; Besendorfer, V.; Puizina, J. Essential Oil Composition and Internal Transcribed Spacer (ITS) Sequence Variability of Four South-Croatian Satureja Species (Lamiaceae). Molecules 2009, 14, 925-938, https://doi.org/10.3390/molecules14030925.

31. Ciccarelli, D.; Garbari, F.; Pagni, A. M. The Flower of Myrtus Communis (Myrtaceae): Secretory Structures, Unicellular Papillae, and Their Ecological Role. Flora Morphol. Distrib. Funct. Ecol. Plants 2008, 203, 8593, https://doi.org/10.1016/j.flora.2007.01.002.

32. Gershenzon, J. Metabolic Costs of Terpenoid Accumulation in Higher Plants. J. Chem. Ecol. 1994, 20, 12811328, https://doi.org/10.1007/BF02059810.

33. Liolios, C.C.; Graikou, K.; Skaltsa, E.; Chinou, I. Dittany of Crete: A Botanical and Ethnopharmacological Review. J. Ethnopharmacol. 2010, 131, 229-241, https://doi.org/10.1016/j.jep.2010.06.005.

34. Morone-Fortunato, I.; Montemurro, C.; Ruta, C.; Perrini, R.; Sabetta, W.; Blanco, A.; Lorusso, E.; Avato, P. Essential Oils, Genetic Relationships and in Vitro Establishment of Helichrysum Italicum (Roth) G. Don Ssp. Italicum from Wild Mediterranean Germplasm. Ind. Crops Prod. 2010, 32, 639-649, https://doi.org/10.1016/j.indcrop.2010.07.023.

35. Sangwan, N.S.; Farooqi, A.H.A.; Shabih, F.; Sangwan, R.S. Regulation of Essential Oil Production in Plants. Plant Growth Regul. 2001, 34, 3-21, https://doi.org/10.1023/A:1013386921596.

36. Wagner, G.J. Secreting Glandular Trichomes: More than Just Hairs. Plant Physiol. 1991, 96, 675-679, https://doi.org/10.1104/pp.96.3.675.

37. Djilani, A.; Dicko, A. The Therapeutic Benefits of Essential Oils. Nutr. Well-Being Heal. 2010, $155-178$.

38. Vikas Gupta, P.M.; Bansal, P.; Khokra, S.L.; Kaushik, D. Pharmacological Potential of Matricaria RecutitaA Review. Int. J. Pharm. Sci. Drug Res. 2010, 2, 12-16.

39. Bergougnoux, V.; Caissard, J.C.; Jullien, F.; Magnard, J. L.; Scalliet, G.; Cock, J.M.; Hugueney, P.; Baudino, S. Both the Adaxial and Abaxial Epidermal Layers of the Rose Petal Emit Volatile Scent Compounds. Planta 2007, 226, 853-866, https://doi.org/10.1007/s00425-007-0531-1.

40. Buchbauer, K.H.C.B.; Buchbauer, G. Handbook of Essential Oils: Science, Technology and Application. Buchbauer, K.H.C.B.; Buchbauer, G. Taylor \& Francis: Boca Raton, 2010; https://doi.org/10.1201/b19393.

41. Harrewijn, P.; Oosten, M.V.A.; Piron, G..P. Natural Terpenoids as Messengers: A Multidisciplinary Study of Their Production, Biological Functions and Practical Applications. First.; Springer Science+Business Media Dordrecht, Volume 58, 2000; https://doi.org/10.1007/978-94-010-0767-2.

42. He, S.; Wang, D.; Zhang, Y.; Yang, S.; Li, X.; Wei, D.; Zhang, M.; Qin, J. Chemical Components and Biological Activities of the Essential Oil from Traditional Medicinal Food, Euryale ferox Salisb., Seeds. Journal of Essential Oil Bearing Plants 2019, 22, 73-81, https://doi.org/10.1080/0972060X.2019.1595165.

43. Harborne, J.B. Common fragrance and flavor materials: by K. Bauer, D. Garbe and H. Surbury, Third Edition, Wiley, VCH, Weinheim, 1997. 278 pp. £60. ISBN 3-517-28850-3. Phytochemistry 1998, 48, https://doi.org/10.1016/s0031-9422(98)00149-6.

44. Bowles, J.E. The Chemistry of Aromatherapeutic Oils. 3rd Editio.; Allen \& Unwin: Australia, 2003.

45. Oedam, A. The Influence of Some Distillation Conditions on Essential Oil Composition. In: Aromatic Plants: Basic and Applied Aspects. Volume 57, 1984; pp. 227-236. https://doi.org/10.1007/bf00047314. 
46. Adam, M.; Čížková, A.; Eisner, A.; Ventura, K. Solid-phase microextraction based method for determination of essential oils components in herbal beverages. Journal of Separation Science 2013, 36, 764-772, https://doi.org/10.1002/jssc.201200714.

47. Richter, J.; Schellenberg, I. Comparison of Different Extraction Methods for the Determination of Essential Oils and Related Compounds from Aromatic Plants and Optimization of Solid-Phase Microextraction / Gas Chromatography. Anal. Bioanal. Chem. 2007, 387, 2207-2217. https://doi.org/10.1007/s00216-006-1045-6.

48. Skalicka-Wozniak, K.; Los, R.; Glowniak, K.; Malm, A. Comparison of hydrodistillation and headspace solid-phase microextraction techniques for antibacterial volatile compounds from the fruits of Seseli libanotis. Nat Prod Commun 2010, 5, 1427-1430.

49. Liu, Y.-P.; Guo, J.-M.; Yan, G.; Zhang, M.-M.; Zhang, W.-H.; Qiang, L.; Fu, Y.-H. Anti-Inflammatory and Antiproliferative Prenylated Isoflavone Derivatives from the Fruits of Ficus carica. Journal of Agricultural and Food Chemistry 2019, 67, 4817-4823, https://doi.org/10.1021/acs.jafc.9b00865.

50. Miyazawa, M.; Nakashima, Y.; Nakahashi, H.; Hara, N.; Nakagawa, H.; Usami, A.; Chavasiri, W. Volatile Compounds with Characteristic Odor of Essential Oil from Magnolia Obovata Leaves by Hydrodistillation and Solvent-Assisted Flavor Evaporation. J. Oleo Sci. 2015, 64, 999-1007, https://doi.org/10.5650/jos.ess15114.

51. Perakis, C.; Louli, V.; Magoulas, K. Supercritical Fluid Extraction of Black Pepper Oil. J. Food Eng. 2005, 71, 386-393, https://doi.org/10.1016/j.jfoodeng.2004.10.049.

52. Asyikin, Z.; Aziz, A.; Ahmad, A.; Hamidah, S.; Setapar, M.; Karakucuk, A. Essential Oils : Extraction Techniques, Pharmaceutical And Therapeutic Potential - A Review Essential Oils : Extraction Techniques, Pharmaceutical And Therapeutic Potential - A Review. Curr. Drug Metab. 2018, 19. https://doi.org/10.2174/1389200219666180723144850.

53. Padrayuttawat, A.; Tamura, H.; Yamao, M. A split injection system for the analysis of purge and trap headspace of the volatile components in Citrus sudachi. Journal of High Resolution Chromatography 1996, 19, 365-369, https://doi.org/10.1002/jhrc.1240190613.

54. Nekoei, M.; Mohammadhosseini, M. Chemical Composition of the Essential Oils and Volatiles of Salvia Leriifolia by Three Different Extraction Methods Prior to Gas Chromatographic- Mass Spectrometric Determination: Comparison of HD with SFME and HS-SPME. J. Essent. Oil-Bearing Plants 2017, 20, https://doi.org/10.1080/0972060X.2017.1305918.

55. Soran, M.L.; Cobzac, S.C.; Varodi, C.; Lung, I.; Surducan, E.; Surducan, V. The extraction and chromatographic determination of the essentials oils fromOcimum basilicumL. by different techniques. Journal of Physics: Conference Series 2009, 182, 1-5, https://doi.org/10.1088/1742-6596/182/1/012016.

56. Mallia, S.; Fernández-García, E.; Olivier Bosset, J. Comparison of purge and trap and solid phase microextraction techniques for studying the volatile aroma compounds of three European PDO hard cheeses. International Dairy Journal 2005, 15, 741-758, https://doi.org/10.1016/j.idairyj.2004.11.007.

57. Myszka, K.; Leja, K.; Majcher, M. A current opinion on the antimicrobial importance of popular pepper essential oil and its application in food industry. Journal of Essential Oil Research 2019, 31, 1-18, https://doi.org/10.1080/10412905.2018.1511482.

58. Zhang, C.Y.; Guo, M. Comparing Three Different Extraction Techniques on Essential Oil Profiles of Cultivated and Wild Lotus (Nelumbo nucifera) Flower. Life (Basel, Switzerland) 2020, 10, 1-9, https://doi.org/10.3390/life10090209.

59. Abeel, S.M. Trends in Purge and Trap. J. Chromatogr. Sci. 1994, 32, 328-338, https://doi.org/10.1093/chromsci/32.8.328.

60. Aboaba, S.; Oladosu, I.; Ekundayo, O. Chemical composition, acetyl cholinesterase inhibitory properties and brine shrimp toxicity of essential oils from Ficus capensis Thunb from Nigeria. International Journal of Biological and Chemical Sciences 2011, 4, 1494-1500, https://doi.org/10.4314/ijbcs.v4i5.65555.

61. Ortiz, S.; Lecsö-Bornet, M.; Michel, S.; Grougnet, R.; Boutefnouchet, S. Chemical Composition and Biological Activity of Essential Oils from Artemisia Copa Phil. Var. Copa (Asteraceae) and Aloysia Deserticola (Phil.) Lu-Irving \& O’Leary (Verbenaceae), Used in the Chilean Atacama's Taira Community (Antofagasta, Chile). J. Essent. Oil Res. 2019, 31, 425-431, https://doi.org/10.1080/10412905.2019.1572549.

62. Yılmaz, G.; Çiçek, M.; Demirci, B.; Başer, K.H.C. Essential Oil Compositions of Subspecies of Scutellaria Brevibracteata Stapf from Turkey. J. Essent. Oil Res. 2019, 31, 255-262, https://doi.org/10.1080/10412905.2019.1579762.

63. Adebayo, M.A.; Aboaba, S.A.; Eresanya, O.I.; Ajetunmobi, A.A.; Ogunwande, I.A. Constituent of Essential Oil from Ficus Benghalensis L. European J. Med. Plants 2015, 9, 1-6, https://doi.org/10.9734/EJMP/2015/18803.

64. Sonibare, M.A.; Sonibare, O.O.; Akharame, O.E.; Soladoye, M.O. Chemical Composition of Essential Oils of Ficus Elasticoidies de Wild., Ficus Ovata Vahl and Ficus Natalensis Subsp. Leprieurii (Miq.) c.c. Berg from Nigeria. J. Essent. Oil-Bearing Plants 2009, 12, 282-286, https://doi.org/10.1080/0972060X.2009.10643721.

65. Foddai, M.; Marchetti, M.; Ruggero, A.; Juliano, C.; Usai, M. Evaluation of Chemical Composition and AntiInflammatory, Antioxidant, Antibacterial Activity of Essential Oil of Sardinian Santolina Corsica Jord. \& Fourr. Saudi J. Biol. Sci. 2018, 26, 930-937, https://doi.org/10.1016/j.sjbs.2018.08.001. 
66. Ogunwande, I.A.; Jimoh, R.; Ajetunmobi, A.A.; Avoseh, N.O.; Flamini, G. Essential Oil Composition of Ficus Benjamina (Moraceae) and Irvingia Barteri (Irvingiaceae). Nat. Prod. Commun. 2012, 7, 1673-1675, https://doi.org/10.1177/1934578X1200701233.

67. Ghorbanpour, M.; Shahhoseini, R. Influence of Distillation Time on the Content and Constituent of Essential Oils Isolated from Lemon Verbena (Lippia Citriodora Kunth). J. Essent. Oil-Bearing Plants 2017, 20, 10831089, https://doi.org/10.1080/0972060X.2017.1345648.

68. Mancianti, F.; Ebani, V.V. Biological Activity of Essential Oils. Molecules 2020, 25, 2-5, https://doi.org/10.3390/molecules25030678.

69. Llorens-Molina, J.A.; Ygueravide, B.; Vacas, S. Essential Oil Composition of Berries of Juniperus Oxycedrus L. Ssp. Oxycedrus According to Their Ripening Stage. J. Essent. Oil Res. 2019, 31, 276-285, https://doi.org/10.1080/10412905.2019.1583140.

70. Benzaid, C.; Tichati, L.; Djeribi, R.; Rouabhia, M. Evaluation of the Chemical Composition, the Antioxidant and Antimicrobial Activities of Mentha $\times$ Piperita Essential Oil against Microbial Growth and Biofilm Formation. J. Essent. Oil-Bearing Plants 2019, https://doi.org/10.1080/0972060X.2019.1622456.

71. Kurti, F.; Giorgi, A.; Beretta, G.; Mustafa, B.; Gelmini, F.; Testa, C.; Angioletti, S.; Giupponi, L.; Zilio, E.; Pentimalli, D.; Hajdari, A. Chemical composition, antioxidant and antimicrobial activities of essential oils of different Pinus species from Kosovo. Journal of Essential Oil Research 2019, 31, 263-275, https://doi.org/10.1080/10412905.2019.1584591.

72. Tuan, D.Q.; Duc, H.V.; Nhan, L.T.; Anh, L.T.; Hoai, N.T.; Raal, A. Constituents of Essential Oils from the Leaves of Paramignya trimera (Oliv.) Guillaum from Vietnam. Journal of Essential Oil Bearing Plants 2019, 22, 391-395, https://doi.org/10.1080/0972060X.2019.1582362.

73. Mamadalieva, N.Z.; Youssef, F.S.; Ashour, M.L.; Sasmakov, S.A.; Tiezzi, A.; Azimova, S.S. Chemical composition, antimicrobial and antioxidant activities of the essential oils of three Uzbek Lamiaceae species. Natural Product Research 2019, 33, 2394-2397, https://doi.org/10.1080/14786419.2018.1443088.

74. Koyama, S.; Heinbockel, T. The Effects of Essential Oils and Terpenes in Relation to Their Routes of Intake and Application. International Journal of Molecular Sciences 2020, 21, 1-36, https://doi.org/10.3390/ijms21051558.

75. Aljaafari, M.; Alhosani, M.S. Essential Oils : Partnering with Antibiotics. In: Essential Oils-Oil of Nature. 2019; pp 1-17, https://doi.org/10.5772/intechopen.86575.

76. Iseppi, R.; Mariani, M.; Cond, C.; Sabia, C.; Messi, P. Essential Oils : A Natural Weapon against AntibioticResistant Bacteria Responsible for Nosocomial Infections. Antibiotics 2021, 10, 1-14, https://doi.org/10.3390/antibiotics10040417.

77. Soo, P.; Yap, X.; Hua, S.; Lim, E.; Ping, C.; Chin, B. Combination of Essential Oils and Antibiotics Reduce Antibiotic Resistance in Plasmid-Conferred Multidrug Resistant Bacteria. Phytomedicine 2013, 20, 710-713, https://doi.org/10.1016/j.phymed.2013.02.013.

78. Cimino, C.; Maurel, O. M.; Musumeci, T.; Bonaccorso, A.; Drago, F.; Maria, E.; Souto, B.; Pignatello, R.; Carbone, C. Essential Oils: Pharmaceutical Applications and Encapsulation Strategies into Lipid-Based Delivery Systems. Pharmaceutics 2021, 13, 1-35, https://doi.org/10.3390/pharmaceutics13030327.

79. Chircov, C.; Miclea, II; Grumezescu, V.; Grumezescu, A.M. Essential Oils for Bone Repair and Regeneration-Mechanisms and Applications. Materials (Basel, Switzerland) 2021, 14, 1-20, https://doi.org/10.3390/ma14081867.

80. Vladu, A.; Marin, S.; Neacsu, I.; Truscă, R.; Kaya, M.; Kaya, D.; Popa, A.-M.; Poiană, C.; Cristescu, I.; Orlov, C. Spongious fillers based on collagen-hydroxyapatite-eugenol acetate with therapeutic potential in bone cancer. Farmacia 2020, 68, 313-321, https://doi.org/10.31925/farmacia.2020.2.17.

81. Croitoru, A.; Oprea, O.; Nicoara, A.; Trusca, R.; Radu, M.; Neacsu, I.; Ficai, D.; Ficai, A.; Andronescu, E. Multifunctional Platforms Based on Graphene Oxide and Natural Products. Medicina (B. Aires). 2019, 55, 1-22, https://doi.org/10.3390/medicina55060230.

82. Dorman, H.J.D.; Deans, S.G. Antimicrobial agents from plants: antibacterial activity of plant volatile oils. Journal of Applied Microbiology 2000, 88, 308-316, https://doi.org/10.1046/j.1365-2672.2000.00969.x.

83. Aćimović, M. Essential Oils: Inhalation Aromatherapy. J. Agron. Technol. Eng. Manag. Rev. 2021, 4, 547557.

84. Özbek, H.; Uğraş, S.; Dülger, H.; Bayram, I.; Tuncer, I.; Öztürk, G.; Öztürk, A. Hepatoprotective Effect of Foeniculum Vulgare Essential Oil. Fitoterapia 2003, 74, 317-319, https://doi.org/10.1016/S0367326X(03)00028-5.

85. Svoboda, K.; Hampson, J.; Hunter, T. Secretory Tissues. Int. J. Aromather. 1999, 9, 124-131.

86. Deans, S. G.; Svoboda, K. P.; Gundidza, M.; Brechany, E. Y. Essential Oil Profiles of Several Temperate and Tropical Aromatic Plants: Their Antimicrobial and Antioxidant Activities. Acta Horticulturae. 1992, 229232, https://doi.org/10.17660/actahortic.1992.306.25.

87. Griffin, S.G.; Wyllie, S.G.; Markham, J.L.; Leach, D.N. The Role of Structure and Molecular Properties of Terpenoids in Determining Their Antimicrobial Activity. Flavour Fragr. J. 1999, 14, 322-332, https://doi.org/10.1002/(SICI)1099-1026(199909/10)14:5<322::AID-FFJ837>3.0.CO;2-4.

88. Pengelly, A. The Constituent of Medicinal Plants. 2nd Editio.; Allen \& Unwin: Australia, 2004. 
89. de Sousa, D.P.; Genival, J.S.; Andrade, L.N.; Batista, J.S. Spasmolytic Activity of Chiral Monoterpene Esters. Rec. Nat. Prod. 2011, 5, 117-122.

90. Sugawara, Y.; Hara, C.; Tamura, K.; Fujii, T.; Nakamura, K.; Masujima, T.; Aoki, T. Sedative Effect on Humans of Inhalation of Essential Oil of Linalool: Anal. Chim. Acta 1998, 365, 293-299, https://doi.org/10.1016/s0003-2670(97)00639-9.

91. Peana, A.T.; D’Aquila, P.S.; Panin, F.; Serra, G.; Pippia, P.; Moretti, M.D.L. Anti-Inflammatory Activity of Linalool and Linalyl Acetate Constituents of Essential Oils. Phytomedicine 2002, 9, 721-726, https://doi.org/10.1078/094471102321621322.

92. Galeotti, N.; Ghelardini, C.; Di Cesare Mannelli, L.; Mazzanti, G.; Baghiroli, L.; Bartolini, A. Local Anaesthetic Activity of (+)- and (-)-Menthol. Planta Med. 2001, 67, 174-176, https://doi.org/10.1055/s-200111515.

93. De Sousa, D.P. Analgesic-like Activity of Essential Oils Constituents. Molecules 2011, 16, 2233-2252, https://doi.org/10.3390/molecules16032233.

94. Mensah-Agyei, G.O.; Ayeni, K.I. GC-MS Analysis of Bioactive Compounds and Evaluation of Antimicrobial Activity of the Extracts of Daedalea Elegans: A Nigerian Mushroom. African J. Microbiol. Res. 2020, 14, 204-210, https://doi.org/10.5897/AJMR2019.9120.

95. Sivakumar, R.; Jebanesan, A.; Govindarajan, M.; Rajasekar, P. Larvicidal and Repellent Activity of Tetradecanoic Acid against Aedes Aegypti ( Linn .) and Culex Quinquefasciatus ( Say .) ( Diptera : Culicidae). Asian Pac. J. Trop. Med. 2011, 4, 706-710, https://doi.org/10.1016/S1995-7645(11)60178-8.

96. Aparna, V.; Kalarickal, V.; Mandal, P.K. Anti-Inflammatory Property of n -Hexadecanoic Acid: Structural Evidence and Kinetic Assessment. Chem. Biol. Drug Des. 2012, 80, 434-439, https://doi.org/10.1111/j.17470285.2012.01418.x.

97. Radhakrishnan, A.J. A Holistic Approach for Microwave Assisted Solvent Extraction of Phenolic Compounds from Ficus Benghalensis Fruits and Its Phytochemical Profiling. J. Food Process Eng. 2020, 43, 1-30, https://doi.org/10.1111/jfpe.13536.

98. Miceli, N.; Taviano, M.F.; Giuffrida, D.; Trovato, A.; Tzakou, O.; Galati, E.M. Anti-Inflammatory Activity of Extract and Fractions from Nepeta Sibthorpii Bentham. J. Ethnopharmacol. 2005, 97, 261-266, https://doi.org/10.1016/j.jep.2004.11.024.

99. Gomes, N.G.M.; Campos, M.G.; Órfão, J.M.C.; Ribeiro, C.A.F. Plants with Neurobiological Activity as Potential Targets for Drug Discovery. Prog. Neuro-Psychopharmacology Biol. Psychiatry 2009, 33, 13721389, https://doi.org/10.1016/j.pnpbp.2009.07.033.

100.Gali-Muhtasib, H.; Hilan, C.; Khater, C. Traditional Uses of Salvia Libanotica (East Mediterranean Sage) and the Effects of Its Essential Oils. J. Ethnopharmacol. 2000, 71, 513-520, https://doi.org/10.1016/S03788741(99)00190-7.

101.Ojo, O.A.; Akintayo, C. Assessment of Antioxidant Activity of Ficus Asperifolia Miq Aqueous Extract - In Vitro Studies. J. Phytopharm. 2014, 3, 16-21.

102.Fasina, K.A.; Adesetan, T.O.; Oseghale, F.; Egberongbe, H.O.; Aghughu, O.O.; Akpobome, F.A. Bacteriological and Phytochemical Assessment of Ficus Asperifolia Linn. Infusion. Biomed Res. Int. 2020, 2020, https://doi.org/10.1155/2020/9762639.

103.Nwankwo, I.U.; Ukaegbu-Obi, K.M. Preliminary Phytochemical Screening and Antibacterial Activity of Two Nigerian Medicinal Plants ( Ficus Asperifolia and Terminalis Catappa ). J. Med. Plant Herb. Ther. Res. 2014, 2, 1-5.

104.Lawal, O.A.; Adebayo, M.A.; Sikiru, A.A.; Ogunwande, I.A. Chemical Composition and Antimicrobial Activity of Essential Oils of Ficus Asperifolia Miq. and Ficus Capensis Thunb from Nigeria. J. Essent. OilBearing Plants 2016, 19, 1693-1700, https://doi.org/10.1080/0972060X.2016.1226963.

105.Narasimhan, B.; Dhake, A.S. Antibacterial principles from Myristica fragrans seeds. Journal of medicinal food 2006, 9, 395-399, https://doi.org/10.1089/jmf.2006.9.395.

106. Hsouna, A.B.; Hamdi, N.; Halima, N.B.; Abdelkafi, S. Characterization of Essential Oil from Citrus Aurantium L. Flowers: Antimicrobial and Antioxidant Activities. J. Oleo Sci. 2013, 62, 763-772, https://doi.org/10.5650/jos.62.763.

107.Lawal, O.A.; Ogunwande, I.A.; Salvador, A.F.; Sanni, A.A.; Opoku, A.R. Pachira glabra Pasq. essential oil: chemical constituents, antimicrobial and insecticidal activities. Journal of oleo science 2014, 63, 629-635, https://doi.org/10.5650/jos.ess13179.

108. Oloyede, G.K. Toxicity, Antimicrobial and Antioxidant Activities of Methyl Salicylate Dominated Essential Oils of Laportea Aestuans (Gaud). Arab. J. Chem. 2011, 9, https://doi.org/10.1016/j.arabjc.2011.09.019.

109.Motooka, R.; Usami, A.; Nakahashi, H.; Koutari, S.; Nakaya, S.; Shimizu, R.; Tsuji, K.; Marumoto, S.; Miyazawa, M. Characteristic odor components of essential oils from Eurya japonica. Journal of oleo science 2015, 64, 577-584, https://doi.org/10.5650/jos.ess14225.

110. Clery, R. High-impact odorants in essential oils. Flavour and Fragrance Journal 2010, 25, 117-120, https://doi.org/10.1002/ffj.1980.

111. Grown, L.; Ayoub, N.; Singab, A.N.; Mostafa, N.; Schultze, W. Volatile Constituents of Leaves of Ficus Carica Volatile Constituents of Leaves of Ficus Carica Linn . Grown in Egypt. J. Essent. Oil-Bearing Plants 2013, 13, 316-321, https://doi.org/10.1080/0972060X.2010.10643827. 
112.Sonibare, M.A.; Ogunwande, I.A.; Walker, T.M.; Setzer, W.N.; Soladoye, M.O.; Essien, E. Volatile Constituents of Ficus Exasperata Leaves. Natural Product Communications 2006, 1, 763-765, https://doi.org/10.1177/1934578X0600100912.

113. Ogunwande, I.; Sonibare, M.; Thang, T.; Dung, N.; Soladoye, M.; Morohunfolu, O. Comparative Analysis of the Oils of Three Ficus Species from Nigeria. Journal of Essential Oil Research - J ESSENT OIL RES 2008, 20, 386-389, https://doi.org/10.1080/10412905.2008.9700037.

114.Poudel, A.; Satyal, P.; Setzer, W.N. Composition and Bioactivities of the Leaf Essential Oil of Ficus religiosa Linn. Am. J. Essent. Oils Nat. Prod. 2015, 2, 16-17.

115. Manocha, N.; Samanta, K.C.; Sharma, V. Evaluation of Anti-Rheumatic Activity of Extract of Stem Bark of Ficus Bengalensis. J. Glob. Pharma Technol. 2011, 3, 31-37.

116.Hassan, H.A.; Allam, A.E.; Abu-Baih, D.H.; Mohamed, M.F.A.; Abdelmohsen, U.R.; Shimizu, K.; Desoukey, S.Y.; Hayallah, A.M.; Elrehany, M.A.; Mohamed, K.M.; Kamel, M.S. Isolation and Characterization of Novel Acetylcholinesterase Inhibitors from: Ficus Benghalensis L. Leaves. RSC Adv. 2020, 10, 36920-36929, https://doi.org/10.1039/d0ra06565j.

117. Yadav, Y.C.; Srivastava, D.N.; Saini, V.; Sighal, S.; Seth, A.K.; Kumar, S. In-Vitro Antioxidant Activity of Methanolic Extraction of Ficus Benghalensis L. Latex. Pharmacologyonline 2011, 1, 140-148.

118. Baheti, J.R.; Goyal, R.K. Evaluation of Hepatoprotective Activity of Ficus Bengalensis. Int. J. Res. Pharm. Sci. 2011, 2, 522-525.

119.Arimah, B.D.; Ogunlowo, O.P.; Adebayo, M.A. Phytochemical Analysis and Comparison of In-Vitro Antimicrobial Activities of the Leaf, Stem Bark and Root Bark of Ficus Benghalensis. IOSR J. Pharm. 2013, 3, 33-38, https://doi.org/10.9790/3013-034103338.

120.Taur, D.J.; Nirmal, S.A.; Patil, R.Y.; Kharya, M.D. Antistress and Antiallergic Effects of Ficus Bengalensis Bark in Asthma. Nat. Prod. Res. 2007, 21, 1266-1270, https://doi.org/10.1080/14786410701757330.

121.Thakare, V.N.; Suralkar, A.A.; Deshpande, A.D.; Naik, S.R. Stem Bark Extraction of Ficus Bengalensis Linn for Anti-Inflammatory and Analgesic Activity in Animal Models. Indian J. Exp. Biol. 2010, 48, 39-45.

122. Matpal, M.; Agarwal, K.; Saini, P. In Vitro Antiinflammatory Activity of Ficus Benghalensis Bark. Int. Res. J. Pharm. 2013, 4, 107-108, https://doi.org/10.7897/2230-8407.04723.

123. Angala Parameswari, S.; Mohamed Saleem, T.S.; Chandrasekar, K.B.; Madhusudhana Chetty, C. Protective Role of Ficus Benghalensis against Isoniazid-Rifampicin Induced Oxidative Liver Injury in Rat. Brazilian J. Pharmacogn. 2012, 22, 604-610, https://doi.org/10.1590/S0102-695X2012005000009.

124. Ravi Kiran, S.; Sita Devi, P. Evaluation of Mosquitocidal Activity of Essential Oil and Sesquiterpenes from Leaves of Chloroxylon Swietenia DC. Parasitol. Res. 2007, 101, 413-418, https://doi.org/10.1007/s00436007-0485-z.

125.Casiglia, S.; Bruno, M.; Bramucci, M.; Quassinti, L.; Lupidi, G.; Fiorini, D.; Maggi, F. Kundmannia sicula (L.) DC: a rich source of germacrene D. Journal of Essential Oil Research 2017, 2905, https://doi.org/10.1080/10412905.2017.1338625.

126. Hartsel, J.A.; Eades, J.; Hickory, B. Cannabis Sativa and Hemp. In: Nutraceuticals. Elsevier Inc., 2016 ; pp. 735-754, https://doi.org/10.1016/B978-0-12-802147-7.00053-X.

127.Dhifi, W.; Bellili, S.; Jazi, S.; Bahloul, N.; Mnif, W. Essential Oils' Chemical Characterization and Investigation of Some Biological Activities: A Critical Review. Medicines 2016, 3, 1-16, https://doi.org/10.3390/medicines3040025.

128.Eluchie, C.N.; Oranusi, S.; Akujobi, C.O. Efect of Phytol on Dehydrogenase Activity of Bacterial Isolates from Grilled Meat. Am. J. Food Sci. Technol. 2016, 4, 1-6.

129.McGinty, D.; Letizia, C.S.; Api, A.M. Fragrance Material Review on Phytol. Food Chem. Toxicol. 2010, 48, S59-S63, https://doi.org/10.1016/j.fct.2009.11.012.

130.Hazekamp, A.; Tejkalová, K.; Papadimitriou, S. Cannabis: From Cultivar to Chemovar II-A Metabolomics Approach to Cannabis Classification. Cannabis and Cannabinoid Research 2016, 1, 202-215, https://doi.org/10.1089/can.2016.0017.

131.Selestino Neta, M.C.; Vittorazzi, C.; Guimarães, A.C.; Martins, J.D.L.; Fronza, M.; Endringer, D.C.; Scherer, R. Effects of $\beta$-caryophyllene and Murraya paniculata essential oil in the murine hepatoma cells and in the bacteria and fungi 24-h time-kill curve studies. Pharmaceutical Biology 2017, 55, 190-197, https://doi.org/10.1080/13880209.2016.1254251.

132. Russo, E.B.; Marcu, J. Cannabis Pharmacology: The Usual Suspects and a Few Promising Leads. In: Cannabinoid Pharmacology. Elsevier Inc., Volume 80, 2017; pp. 67-134, https://doi.org/10.1016/bs.apha.2017.03.004.

133.Kim, S.; Baik, J.S.; Tae-Heon, O.; Yoon, W.; Lee, N.H.; Hyun, C. Biological Activities of Korean Citrus Obovoides and Citrus Natsudaidai Essential Oils against Acne-Inducing Bacteria. Biosci. Biotechnol. Biochem. 2008, 72, 2507-2513, https://doi.org/10.1271/bbb.70388.

134.Marchese, A.; Arciola, C.R.; Barbieri, R.; Silva, A.S.; Nabavi, S.F.; Tsetegho Sokeng, A.J.; Izadi, M.; Jafari, N.J.; Suntar, I.; Daglia, M.; Nabavi, S.M. Update on Monoterpenes as Antimicrobial Agents: A Particular Focus on p-Cymene. Materials 2017, 10, 1-15, https://doi.org/10.3390/ma10080947. 
135.Silva, A.C.R.d.; Lopes, P.M.; Azevedo, M.M.B.d.; Costa, D.C.M.; Alviano, C.S.; Alviano, D.S. Biological Activities of a-Pinene and $\beta$-Pinene Enantiomers. Molecules 2012, 17, 6305-6316, https://doi.org/10.3390/molecules17066305.

136.Lamamra, M.; Laouer, H.; Amira, S.; Erdogan Orhan, I.; Senol, F.; Demirci, B.; Akkal, S. Chemical Composition and Cholinesterase Inhibitory Activity of Different Parts of Daucus aristidis Coss. Essential Oils from Two Locations in Algeria. Records of Natural Products 2017, 11, 147-156.

137.Calva, J.; Bec, N.; Gilardoni, G.; Larroque, C.; Cartuche, L.; Bicchi, C.; Montesinos, J.V. Acorenone B: $\mathrm{AChE}$ and BChE Inhibitor as a Major Compound of the Essential Oil Distilled from the Ecuadorian Species Niphogeton dissecta (Benth.) J.F. Macbr. Pharmaceuticals 2017, 10, https://doi.org/10.3390/ph10040084.

138. Cheng, S.-S.; Wu, C.-L.; Chang, H.-T.; Kao, Y.-T.; Chang, S.-T. Antitermitic and Antifungal Activities of Essential Oil of Calocedrus formosana Leaf and Its Composition. Journal of Chemical Ecology 2004, 30, 1957-1967, https://doi.org/10.1023/B:JOEC.0000045588.67710.74.

139.Bonesi, M.; Menichini, F.; Tundis, R.; Loizzo, M.R.; Conforti, F.; Passalacqua, N.G.; Statti, G.A.; Menichini, F. Acetylcholinesterase and butyrylcholinesterase inhibitory activity of Pinus species essential oils and their constituents. Journal of Enzyme Inhibition and Medicinal Chemistry 2010, 25, 622-628, https://doi.org/10.3109/14756360903389856.

140.Zhang, J.-h.; Sun, H.-L.; Chen, S.-Y.; Zeng, L.; Wang, T.-T. Anti-fungal activity, mechanism studies on $\alpha-$ Phellandrene and Nonanal against Penicillium cyclopium. Botanical Studies 2017, 58, 1-9, https://doi.org/10.1186/s40529-017-0168-8.

141. Chen, W.; Vermaak, I.; Viljoen, A. Camphor-A Fumigant during the Black Death and a Coveted Fragrant Wood in Ancient Egypt and Babylon-A Review. Molecules 2013, 18, 5434-5454, https://doi.org/10.3390/molecules18055434.

142.Grecco, S.d.S.; Martins, E.G.A.; Girola, N.; de Figueiredo, C.R.; Matsuo, A.L.; Soares, M.G.; Bertoldo, B.d.C.; Sartorelli, P.; Lago, J.H.G. Chemical composition and in vitro cytotoxic effects of the essential oil from Nectandra leucantha leaves. Pharmaceutical Biology 2015, 53, 133-137, https://doi.org/10.3109/13880209.2014.912238.

143.Türkez, H.; Çelik, K.; Toğar, B. Effects of copaene, a tricyclic sesquiterpene, on human lymphocytes cells in vitro. Cytotechnology 2014, 66, 597-603, https://doi.org/10.1007/s10616-013-9611-1.

144. Aydin, E.; Türkez, H.; Taşdemir, Ş. Anticancer and Antioxidant Properties of Terpinolene in Rat Brain Cells. Archives of Industrial Hygiene and Toxicology 2013, 64, 415-424, https://doi.org/10.2478/10004-1254-642013-2365.

145.Gonçalves, M.J.; Cruz, M.T.; Tavares, A.C.; Cavaleiro, C.; Lopes, M.C.; Canhoto, J.; Salgueiro, L. Composition and biological activity of the essential oil from Thapsia minor, a new source of geranyl acetate. Industrial Crops and Products 2012, 35, 166-171, https://doi.org/10.1016/j.indcrop.2011.06.030.

146.Zhu, Y.; Zhou, H.; Hu, Y.; Tang, J.; Su, M.; Guo, Y.; Chen, Q.; Liu, B. Antityrosinase and Antimicrobial Activities of 2-Phenylethanol , 2-Phenylacetaldehyde and 2-Phenylacetic Acid. Food Chem. 2011, 124, 298302, https://doi.org/10.1016/j.foodchem.2010.06.036.

147. Mulyaningsih, S.; Sporer, F.; Reichling, J.; Wink, M.; Mulyaningsih, S.; Sporer, F.; Reichling, J.; Wink, M. Antibacterial Activity of Essential Oils from Eucalyptus and of Selected Components against MultidrugResistant Bacterial Pathogens Antibacterial Activity of Essential Oils from Eucalyptus and of Selected Components against Multidrug-Resistant Bacterial P. Pharm. Biol. 2011, 49, 893-899, https://doi.org/10.3109/13880209.2011.553625.

148.Imran, M.; Rasool, N.; Rizwan, K.; Zubair, M.; Riaz, M.; Zia-ul-haq, M.; Rana, U. A.; Nafady, A.; Jaafar, H. Z. E. Chemical Composition and Biological Studies of Ficus Benjamina. Chem. Cent. J. 2014, 8, 1-10, https://doi.org/10.1186/1752-153X-8-12.

149.Grison, L.; Edwards, A. A.; Hossaert-McKey, M. Interspecies Variation in Floral Fragrances Emitted by Tropical Ficus Species. Phytochemistry 1999, 52, 1293-1299, https://doi.org/10.1016/S00319422(99)00411-2.

150.Caputo, L.; Smeriglio, A.; Trombetta, D.; Cornara, L.; Trevena, G.; Valussi, M.; Fratianni, F.; De Feo, V.; Nazzaro, F. Chemical Composition and Biological Activities of the Essential Oils of Leptospermum Petersonii and Eucalyptus Gunnii. Front. Microbiol. 2020, 11, 1-15, https://doi.org/10.3389/fmicb.2020.00409.

151.Ezeigwe, O.C.; Nzekwe, F.A.; Nworji, O.F.; Ezennaya, C.F.; Iloanya, E.L.; Asogwa, K.K. Effect of Aqueous Extract of F. Capensis Leaves and Its Combination with c. Aconitifolius Leaves on Essential Biochemical Parameters of Phenylhydrazine-Induced Anemic Rats. J. Exp. Pharmacol. 2020, 12, 191-201, https://doi.org/10.2147/JEP.S254003.

152. Ayinde, B.; Owolabi, O. Effects of the Aqueous Extract of Ficus Capensis Thunb.(Moraceae) Leaf on Gastrointestinal Motility. J. Pharmacogn. Phyther. 2009, 1, 31-35.

153. Oyeleke, S.B.; Dauda, B.E.N.; Boye, O.A. Antibacterial Activity of Ficus Capensis. African J. Biotechnol. 2008, 7, 1414-1417.

154. Mclaughlin, J.L.; Chang, C.; Smith, D.L. Simple Bench-Top Bioassays (Brine Shrimp and Potato Discs ) for the Discovery of Plant Antitumor Compounds. In: Human Medicinal Agents from Plants. ACS Symposium 
Series; American Chemical Society: Washington DC., 1993; pp 112-137, https://doi.org/10.1021/bk-19930534.ch009.

155.Gnanavel. V. and Mary Saral A. GC-MS Analysis of Petroleum Ether and Ethanol Leaf Extracts from Abrus Precatorius LINN . Int. J. Pharma Bio Sci. ISSN 2013, 4, 37-44.

156. Baraket, G.; Saddoud, O.; Chatti, K.; Mars, M.; Marrakchi, M.; Trifi, M.; Salhi-Hannachi, A. Sequence Analysis of the Internal Transcribed Spacers (ITSs) Region of the Nuclear Ribosomal DNA (NrDNA) in Fig Cultivars (Ficus Carica L.). Sci. Hortic. (Amsterdam) 2009, 120, 34-40. https://doi.org/10.1016/j.scienta.2008.09.013.

157.Duke, J.A. CRC Handbook of Medicinal Herbs. Volume 5, 1990; https://doi.org/10.1097/00004850199001000-00014.

158. Guarrera, P.M. Traditional Phytotherapy in Central Italy (Marche, Abruzzo, and Latium). Fitoterapia 2005, 76, 1-25, https://doi.org/10.1016/j.fitote.2004.09.006.

159.Jeong, M.-R.; Kim, H.-Y.; Cha, J.-D. Antimicrobial Activity of Methanol Extract from Ficus carica Leaves Against Oral Bacteria. Jbv 2009, 39, 97-102, https://doi.org/10.4167/jbv.2009.39.2.97.

160.Berg, C.C. Classification and Distribution of Ficus. Experientia 1989, 45, 605-611, https://doi.org/10.1007/BF01975677.

161.Ahmed, F.; Kk, M.A.; Abedin, Z.; Karim, A.A. Traditional Uses and Pharmacological Potential of Ficus Exasperata Vahl. Syst. Rev. Pharm. 2012, 3, 15-23.

162.Wahua, C.; Odogwu, C.A.; Ukomadu, J. Macro- and Micro-Morphological Characteristics and Phytochemical Constituents of Ficus Exasperata Vahl. of Moraceae. Sch. Acad. J. Biosci. 2021, 9, 111-115, https://doi.org/10.36347/sajb.2021.v09i04.002.

163.Bafor, E.E.; Uwumarongie, H.O.; Idiake, J.O. Antipyretic Effects of the Aqueous, Ethyl Acetate and Hexane Leaf Extracts of Ficus Exasperata (Moraceae) in Mice. J. Therm. Biol. 2010, 35, 275-279, https://doi.org/10.1016/j.jtherbio.2010.05.011.

164.Nworu, C.S.; Nwuke, H.C.; Akah, P.A.; Okoye, F.B.C.; Esimone, C.O. Extracts of Ficus exasperata leaf inhibit topical and systemic inflammation in rodents and suppress LPS-induced expression of mediators of inflammation in macrophages. Journal of Immunotoxicology 2013, 10, 302-310, https://doi.org/10.3109/1547691X.2012.732121.

165.Adewole, S.O.; Adenowo, T.; Naicker, T.; Ojewole, J.A. Hypoglycaemic and hypotensive effects of Ficus exasperata vahl. (Moraceae) leaf aqueous extract in rats. African journal of traditional, complementary, and alternative medicines 2011, 8, 275-283, https://doi.org/10.4314/ajtcam.v8i3.65290.

166. Vincent, P.K.; Titanji, D.Z. The Antimalarial Potential of Medicinal Plants Used for the Treatment of Malaria in Cameroonian Folk Medicine. African J. Tradtional Complement. Altern. Med. 2008, 5, 302-321.

167.Focho, D.A.; Tacham, W.; Fonge, B. Medicinal plants of Aguambu-Bamumbu in the Lebialem highlands, Southwest Province of Cameroon. African Journal of Pharmacy and Pharmacology 2009, 3, 001-013.

168. Noumi, E.; Yomi, A. Medicinal plants used for intestinal diseases in Mbalmayo Region, Central Province, Cameroon. Fitoterapia 2001, 72, 246-254, https://doi.org/10.1016/S0367-326X(00)00288-4.

169. Odunbaku, O.; Illusanya, O.A.; Akasoro, K. Antibacterial activity of ethanolic leaf extract of Ficus exasperata on Escherichia coli and Staphylococcus albus. Scientific Research and Essays 2008, 3, 562-564.

170. Aligiannis, N.; Kalpoutzakis, E.; Mitaku, S.; Chinou, I.B. Composition and Antimicrobial Activity of the Essential Oils of Two Origanum Species. J. Agric. Food Chem. 2001, 49, 4168-4170, https://doi.org/10.1021/jf001494m.

171. Bagamboula, C.F.; Uyttendaele, M.; Debevere, J. Inhibitory effect of thyme and basil essential oils, carvacrol, thymol, estragol, linalool and p-cymene towards Shigella sonnei and S. flexneri. Food Microbiology 2004, 21, 33-42, https://doi.org/10.1016/S0740-0020(03)00046-7.

172.de Carvalho, P.M.; Rodrigues, R.F.O.; Sawaya, A.C.H.F.; Marques, M.O.M.; Shimizu, M.T. Chemical composition and antimicrobial activity of the essential oil of Cordia verbenacea D.C. Journal of Ethnopharmacology 2004, 95, 297-301, https://doi.org/10.1016/j.jep.2004.07.028.

173. Bhalla, P.; Tripathi, Y.C.; Varshney, V.K. Phytochemistry and biological activity of Skimmia laureola leaf essential oil - a review. Journal of Essential Oil Research 2021, 33, 315-329, https://doi.org/10.1080/10412905.2021.1895337.

174. Olaokun, O.O. The Value of Extracts of Ficus Lutea (Moraceae) in the Management of Type II Diabetes in a Mouse Obesity Model. University of Pretoria, 2012.

175. Ajaib, M. Phytochemical Screening, Antimicrobial and Antioxidant Activities of Ficus natalensis. JournalChemical Society of Pakistan 2016, 38, 345-351.

176. Kuete, V.; Nana, F.; Ngameni, B.; Mbaveng, A.T.; Keumedjio, F.; Ngadjui, B.T. Antimicrobial activity of the crude extract, fractions and compounds from stem bark of Ficus ovata (Moraceae). Journal of Ethnopharmacology 2009, 124, 556-561, https://doi.org/10.1016/j.jep.2009.05.003.

177.Nasir, A.; Jaafar, F.I.; Muhammad, I.U.; Matazu, K.I.; Yaradua, A.I.; Usman, A.; Suleiman, Z.A.; Sulaiman, H.; Nasir, N.M. Proximate and Mineral Composition of the Fruit of Ficus Polita. J. Appl. Life Sci. Int. 2020, 23, 7-13, https://doi.org/10.9734/jalsi/2020/v23i830178.

178. Recio, M.C; Giner, R.M; Manez, S and Rios, J. . Screening of Tropical Medicinal Plants for Antiinflammatory Activity. Phyther. Res. 1995, 9 (August), 571-574. 
179.Nasir, A.; Sule, M.S.; Alhassan, A.J.; Atiku, M.K.; Muhammad, Y.Y.; Idi, A.; Muhammad, I.U.; Yaradua, A.I.; Matazu, K.I.; Isah, M.B. Characterisation and Hypolipidaemic Activity of Phenylquinoline, and Narceine Isolated from Ficus polita Leaf. International Journal of Biochemistry Research \& Review 2020, 29, 42-54. https://doi.org/10.9734/ijbcrr/2020/v29i830211.

180.Gbeassor, M.; Kedjagni, A.Y.; Koumaglo, K.; de Souza, C.; Agbo, K.; Aklikokou, K.; Amegbo, K.A. In vitro antimalarial activity of six medicinal plants. Phytotherapy Research 1990, 4, 115-117, https://doi.org/10.1002/ptr.2650040309.

181.Kumar Makhija, I.; Sharma, I.P.; Khamar, D. Phytochemistry and Pharmacological Properties of Ficus Religiosa: An Overview. Sch. Res. Libr. Ann. Biol. Res. 2010, 1, 171-180.

182. Suriyakalaa, U.; Ramachandran, R.; Doulathunnisa, J.A.; Aseervatham, S.B.; Sankarganesh, D.; Kamalakkannan, S.; Kadalmani, B.; Angayarkanni, J.; Akbarsha, M.A.; Achiraman, S. Upregulation of Cyp19a1 and PPAR- $\gamma$ in ovarian steroidogenic pathway by Ficus religiosa: A potential cure for polycystic ovary syndrome. Journal of Ethnopharmacology 2021, 267, https://doi.org/10.1016/j.jep.2020.113540.

183.Preethi, R.; Devanathan, V.V.; Loganathan, M. Antimicrobial and Antioxidant Efficacy of Some Medicinal Plants Against Food Borne Pathogens. Adv. Biol. Res. (Rennes). 2010, 4, 122-125.

184.Zaidi, S.F.H.; Yamada, K.; Kadowaki, M.; Usmanghani, K.; Sugiyama, T. Bactericidal Activity of Medicinal Plants, Employed for the Treatment of Gastrointestinal Ailments, against Helicobacter Pylori. J. Ethnopharmacol. 2009, 121, 286-291, https://doi.org/10.1016/j.jep.2008.11.001.

185.Grison-Pigé, L.; Hossaert-McKey, M.; Greeff, J.M.; Bessière, J.-M. Fig volatile compounds-a first comparative study. Phytochemistry 2002, 61, 61-71, https://doi.org/10.1016/S0031-9422(02)00213-3.

186. Sreelekshmi, R.; Latha, P.; Arafat, M.; Sukumaran, S.; Shine, V.J.; Anuja, G.I.; Suja, S.; Rajasekharan, S. Anti-inflammatory, analgesic and anti-lipid peroxidation studies on stem bark of Ficus religiosa Linn. Indian Journal of Natural Products and Resources 2007, 6, 377-381.

187.Guleria, S.; Tiku, A.K.; Gupta, S. Chemical Composition, Antioxidant Activity and Inhibitory Effects of Essential Oil of Eucalyptus Teretecornis Grown in North-Western Himalaya against Alternaria Alternata. $J$. Plant Biochem. Biotechnol. 2012, 21, 44-50, https://doi.org/10.1007/s13562-011-0073-2.

188.Lockett, C.T.; Calvert, C.C.; Grivetti, L.E. Energy and Micronutrient Composition of Dietary and Medicinal Wild Plants Consumed during Drought. Study of Rural Fulani, Northeastern Nigeria. Int. J. Food Sci. Nutr. 2000, 51, 195-208, https://doi.org/10.1080/09637480050029700.

189. Morenike, C.; Veronica, A.; Emikpe, B.O.; Oyebanji, V.O.; Jarikre, T.A. Investigations on the antimicrobial and wound healing activity of Ficus thonningii Blume extracts. Comparative Clinical Pathology 2019, 28, 1113-1118, https://doi.org/10.1007/s00580-019-02948-5.

190.Fokunang, C.N.; Pougoue, J.K.; Fokunang, E.T.; Joseph, E.B.; J, N.; Njinkio, B.N.; MBAH Berinyuy, J.A.; Dobgima, J.F. Evaluation of Antioxidant Properties of Secondary Metabolites in Aqueous Extracts of Ficus Thonningii Blume Tested on Wistar Rats. J. Anal. Pharm. Res. 2020, 9, 27-35, https://doi.org/10.15406/japlr.2020.09.00348.

191.Vetter, W.; Lehnert, K. Di Fferentiation of Refined and Virgin Edible Oils by Means of the Trans - and Cis Phytol Isomer Distribution. J. Agric. Food Chem. 2012, 60, 6103-6107.

192.Daines, A.; Payne, R.; Humphries, M.; Abell, A. The Synthesis of Naturally Occurring Vitamin K and Vitamin K Analogues. Curr. Org. Chem. 2005, 7, 1625-1634, https://doi.org/10.2174/1385272033486279.

193. Netscher, T. Synthesis of Vitamin E. Vitam. Horm. 2007, 76, 155-202, https://doi.org/10.1016/S00836729(07)76007-7.

194.de Moraes, J.; de Oliveira, R.N.; Costa, J.P.; Junior, A.L.G.; de Sousa, D.P.; Freitas, R.M.; Allegretti, S.M.; Pinto, P.L.S. Phytol, a Diterpene Alcohol from Chlorophyll, as a Drug against Neglected Tropical Disease Schistosomiasis Mansoni. PLOS Neglected Tropical Diseases 2014, 8, 1-12, https://doi.org/10.1371/journal.pntd.0002617 .

195.Rontani, J.-F.; Volkman, J.K.; . Phytol Degradation Products as Biogeochemical Tracers in Aquatic Environments. Org. Geochem. 2003, 34, 1-35.

196.Silva, R.O.; Sousa, F.B.M.; Damasceno, S.R.B.; Carvalho, N.S.; Silva, V.G.; Oliveira, F.R.M.A.; Sousa, D.P.; Aragão, K.S.; Barbosa, A.L.R.; Freitas, R.M.; Medeiros, J.V.R. Phytol, a diterpene alcohol, inhibits the inflammatory response by reducing cytokine production and oxidative stress. Fundamental \& Clinical Pharmacology 2014, 28, 455-464, https://doi.org/10.1111/fcp.12049.

197.Sato, K.; Mizuno, S.; Hirayama, M. A Total Synthesis of Phytol. J. Org. Chem. 1967, 32, 177-180, https://doi.org/10.1021/jo01277a043.

198. Andrews, R.E.; Parks, L.W.; Spence, K.D. Some Effects of Douglas Fir Terpenes on Certain Microorganisms. Appl. Environ. Microbiol. 1980, 40, 301-304, https://doi.org/10.1128/aem.40.2.301-304.1980.

199.Kummer, R.; Estevão-Silva, C.; Bastos, R.; Rocha, B.; Spironello, R.; Yamada, A.; Bersani-Amado, C.; Cuman, R. Alpha-pinene reduces in vitro and in vivo leukocyte migration during acute inflammation. International Journal of Applied Research in Natural Products 2015, 8, 12-17.

200.Him, A.n.; Özbek, H.; Türel, I.; Öner, A.C. Antinociceptive Activity of Alpha-Pinene and Fenchone. Pharmacologyonline 2008, 3, 363-369. 
201.Sharma, C.; Al, J.M.; Nurulain, S.M.; Goyal, S.N.; Amjad, M.; Shreesh, O. Polypharmacological Properties and Therapeutic Potential of -Caryophyllene : A Dietary Phytocannabinoid of Pharmaceutical Promise. Curr. Pharm. Des. 2016, 22, 1-28.

202.Selestino Neta, M.C.; Vittorazzi, C.; Guimarães, A.C.; Martins, J.D.L.; Fronza, M.; Endringer, D.C.; Scherer, R. Effects of $\beta$-caryophyllene and Murraya paniculata essential oil in the murine hepatoma cells and in the bacteria and fungi 24-h time-kill curve studies. Pharmaceutical Biology 2017, 55, 190-197, https://doi.org/10.1080/13880209.2016.1254251.

203.Sköld, M.; Karlberg, A.-T.; Matura, M.; Börje, A. The fragrance chemical $\beta$-caryophyllene-air oxidation and skin sensitization. Food and Chemical Toxicology 2006, 44, 538-545, https://doi.org/10.1016/j.fct.2005.08.028.

204.Xiao, Z.; Li, Q.; Niu, Y.; Zhou, X.; Liu, J.; Xu, Y.; Xu, Z. Odor-active compounds of different lavender essential oils and their correlation with sensory attributes. Industrial Crops and Products 2017, 108, 748-755, https://doi.org/10.1016/j.indcrop.2017.07.040.

205.Acree, T.E.; Barnard, J.; Cunningham, D.G. A procedure for the sensory analysis of gas chromatographic effluents. Food Chemistry 1984, 14, 273-286, https://doi.org/10.1016/0308-8146(84)90082-7.

206. Grosch, W. Detection of Potent Odorants in Foods by Aroma Extract Dilution. Trends Food Sci. Technol. 1993, 4, 68-73, https://doi.org/10.1016/0924-2244(93)90187-F.

207.Steinhaus, M.S.; Inuco, D.S.; Olster, J.P.; Sorio, C.O.; Peter, S. Characterization of the Key Aroma Compounds in Pink Guava ( Psidium Guajava L .) by Means of Aroma Re-Engineering Experiments and Omission Tests. J. Agric. Food Chem. 2009, 57, 2882-2888, https://doi.org/10.1021/jf803728n. 